\title{
Investigation of Activity Designs Prepared by Pre- Service Mathematics Teachers for Aspects of Entrepreneurship Education*
}

\author{
Elif Nur AKKAŞ ${ }^{* *}$
}

\begin{abstract}
The aim of this study is to examine examples of activities prepared by preservice mathematics teachers for entrepreneurship education based on their knowledge of the aspects of entrepreneurship education and the achievements in this area in the secondary school mathematics curriculum. In the national and international literature, there are very few studies on entrepreneurship skills in mathematics education and on developing these skills. In addition, there are no secondary school mathematics curriculum acquisitions or application examples prepared in accordance with such acquisitions. The participants of this study included 20 pre-service teachers enrolled in the third-year undergraduate course "Connection in Mathematics Teaching" who volunteered to participate. Over the course of two weeks, four lessons of approximately 40 minutes, or 160 minutes in total, were taught to pre-service teachers addressing the following questions: "What are entrepreneurship and entrepreneurial skills? How are they related to mathematics? What can be done about the achievements in mathematics and the mathematics curriculum?" The subjects were explained and examples of applications from the researcher's own work were given. After these explanations, the pre-service teachers were given an assignment. The data of the research consist of the completed assignments and audio recordings of individual interviews after homework analysis. The data were analyzed by content analysis.
\end{abstract}

Keywords: Connection in mathematics teaching, entrepreneurship, entrepreneurship education aspects, activity design, pre-service mathematics teacher

\footnotetext{
${ }^{*}$ Ethics committee approval for this study was obtained from the Ethics Committee of Human Research in Social Sciences, Bolu Abant İzzet Baysal University, dated 01.06.2021 and numbered 2021/217.

** Orcid ID: https://orcid.org/0000-0002-8286-8203, Assist. Prof. Dr., Bolu Abant İzzet Baysal University, Turkey, elifnurakdogan@hotmail.com
} 


\section{INTRODUCTION}

In contemporary society, which has passed from the age of industrial society to the age of information and technology, human profiles with logical and practical intelligence come to the fore, being more important than physical labor. In this sense, education is the most important element in producing entrepreneurial individuals who can keep up with the rapid changes of the age. Education is one of the most helpful factors for individuals in gaining and developing entrepreneurship and entrepreneurship skills. Entrepreneurship training is carried out to increase entrepreneurial activities in this direction, transferring skills to individuals within the framework of the unique cultural context of each country (Lee \& Peterson, 2000). The concepts of entrepreneurship and entrepreneurial skills in Turkey have been on the agenda of the Ministry of National Education since 2005. The Ministry of National Education (2005) defined entrepreneurship as "to have empathy, to show harmonious behaviors in human relations, to plan, to implement the plan, to take risks and to realize the product needed in any field" and adapted this concept to the education process. In order to produce entrepreneurial individuals, entrepreneurship skills should be addressed first. Entrepreneurship skills are defined as the skills required to put one's feelings and thoughts into action, to make a plan to achieve a targeted goal, to manage the process and take risks, and to realize creative and innovative skills (Figel, 2006, pp. 3-12). Various training approaches are used to instill these skills. The main purpose of entrepreneurship training is to build both entrepreneurship awareness and entrepreneurship skills (Ağca, 2007). However, when the national and international literature is examined, it is seen that entrepreneurship education is mostly considered in fields such as social sciences, economics and administrative sciences, and engineering (Wang \& Wong, 2004; İşcan \& Kaygın, 2011; Uygun et al., 2012; Bilge \& Bal, 2012; Korkmaz, 2012; Pan \& Akay, 2015). In the training given for gaining entrepreneurship skills, there are five essential areas in which individuals should grow. These are the business idea, financing, product design-production, promotion-marketing, and investment aspects (see Appendix 1). These aspects are sub-divided into skills. In the process of entrepreneurship education, important aspects for investment include the following: information that will help students in the creation of business ideas; fundamental considerations in the process of moving from the realization of the business idea to the end of the investment process and financing; the design process and production of the product, after the financing stage; determination of the market and marketing opportunities of the product; concrete promotion and marketing; and, finally, ensuring production possibilities and the continuity of the realized business idea, product, or service (Tarhan, 2019).

Explaining entrepreneurship education as a process, Fayolle (2006, p. 702) emphasizes pedagogical programs or training processes that include gaining attitudes, skills, and personal qualities related to entrepreneurship. In this direction, it would be appropriate to provide training on entrepreneurship and entrepreneurship skills in the education faculties of universities. In entrepreneurship education, students are expected to turn 
entrepreneurship education into practice (Clegg et al., 2005). Rather than being a strict, prescriptive, completely results-oriented education, entrepreneurship education must allow the talents and skills of the people receiving the education to be revealed (Bulut \& Aslan, 2014). In this direction, it can be thought that courses to be given in faculties of education for entrepreneurship and entrepreneurship skills will activate the thinking processes of pre-service teachers and, at the same time, will ensure success in creating different initiatives for students in the schools they are assigned to.

\section{Aim of the study}

This study was designed to determine how well pre-service teachers know the concepts of entrepreneurship and entrepreneurship skills in the mathematics curriculum before they begin their professional careers. Whether or not they had taken a course on entrepreneurship in the faculty of education was also examined, together with the contribution of that education for pre-service teachers. The activities of the participants were examined. Based on these examinations, the needs in the education process were determined and ways to use entrepreneurship and entrepreneurship skills more frequently in daily life and mathematics education were identified. This study will guide future developmental research to be carried out in relation to entrepreneurship education and mathematics teaching in teacher education. The aim of this study is to examine examples of activities prepared by pre-service mathematics teachers for entrepreneurship education based on their knowledge of the aspects of entrepreneurship education and the achievements for this information in the secondary school mathematics curriculum. For this purpose, answers to the following questions were sought in this study:

1) What do pre-service mathematics teachers know about "entrepreneurship education and its aspects" before receiving entrepreneurship education?

2) How do pre-service mathematics teachers connect mathematics teaching with entrepreneurship education after entrepreneurship education?

3) How do pre-service mathematics teachers plan to be beneficial to their students as a result of the education they receive?

4) How do pre-service mathematics teachers determine the achievements they chose in the secondary school mathematics course with the activity examples they prepared regarding entrepreneurship education?

\section{Importance of the study}

When the current courses offered in departments of mathematics teaching in education faculties are examined, the most appropriate course for entrepreneurship and entrepreneurship skills is the course entitled "connections in mathematics teaching" because the basis of this course is the "connection process." Coxford (1995) defined this linking process in general as "a very broad set of ideas and processes that can be used to link different topics in mathematics." Based on this definition, "mathematics education" and "entrepreneurial skills" can be connected with each other to link different subjects and generate new ideas (Akkaş et al., 2020; Tarhan et al., 2021). In addition, in 
entrepreneurship education, individuals are expected to transform entrepreneurship education into practice (Clegg et al., 2005). In addition to this, it is important that entrepreneurship education be given the opportunity to reveal the talents and skills of the people who receive the education, rather than being a strict, prescriptive, and resultoriented form of education (Bulut \& Aslan, 2014). Considering all these points, it can be thought that pre-service teachers' preparation of activities by connecting mathematics teaching and entrepreneurship education will provide success in creating different initiatives for their students in the future, as it will be a new and creative experience for pre-service teachers and will activate their thinking processes.

For the above reasons, it is believed that this study will make important contributions to the literature. No other study has been found in the literature examining activities prepared by pre-service mathematics teachers regarding aspects of entrepreneurship education.

\section{METHOD}

\section{Research Design}

In this study, a case study approach, as one of the descriptive research methods, was used. In case studies, details of the data obtained from a determined event, group, or particular case are evaluated while trying to examine cause-effect relationships (Çepni, 2012).

\section{Participants}

The participants of the study comprised a total of 20 pre-service mathematics teachers, with 10 women and 10 men, all third-year undergraduate pre-service mathematics teachers studying in an education faculty. Pre-service teachers from the third-year of undergraduate study were chosen because the activity samples to be prepared were suitable for the "connection in mathematics teaching" course and that course is an undergraduate third-year course. The "connection in mathematics teaching" course was chosen to connect mathematics with entrepreneurship and entrepreneurship skills and thus see the extent to which pre-service teachers learn these concepts in this course through the activity assignments they completed. For these reasons, the criterion sampling method, one of the sampling methods for qualitative research purposes, was used in the selection of the participants. Attention was paid to the willingness of the participants to volunteer in the study.

\section{Application process and data collection tools}

This study was carried out with 20 pre-service teachers who took the "connection in mathematics teaching" course and volunteered to participate in the research. This course is a compulsory course in the third year and sixth semester of the undergraduate program. The official course description is as follows: "Exploring the connections between concepts and operations; expressing mathematical concepts and rules with 
different representations; connecting different mathematical concepts with each other; linking mathematics with other subjects; connecting mathematics with daily life" (YÖK, 2018). Based on this definition and Coxford's (1995) definition of connection, aspects of entrepreneurship education and sub-skills were adapted in line with mathematical skills in mathematics teaching, and this connection process was used in the education given to pre-service mathematics teachers. In this adaptation process, the studies of Akkaş et al. (2020) and Tarhan et al. (2021) were utilized, based on the primary/secondary school mathematics curriculum and gaining entrepreneurship skills. The training process is illustrated in Figure 1.
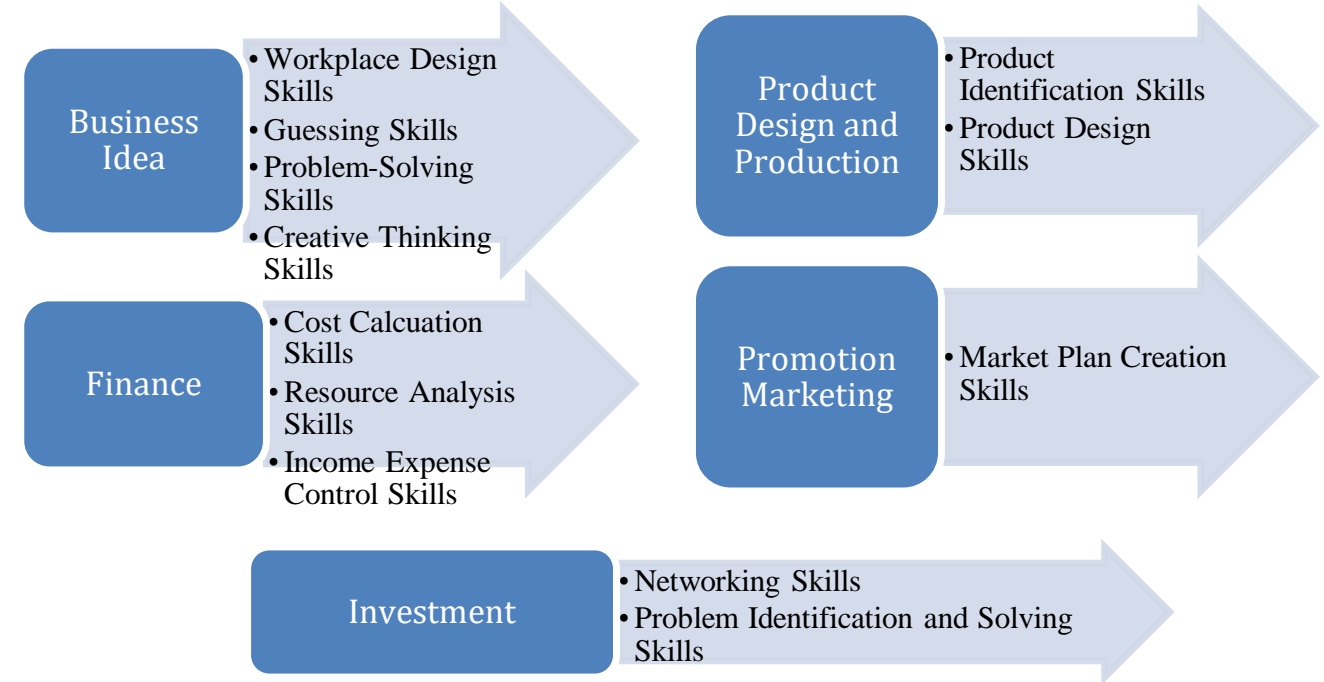

- Networking Skills

- Problem Identification and Solving Skills

Figure 1. The Five Aspects of Entrepreneurial Skills and Skills Related to Teaching Mathematics

Within the scope of the course, over two weeks, four lessons of approximately 40 minutes, or 160 minutes in total, were delivered, addressing the following questions: "What are entrepreneurship and entrepreneurial skills?" "How are they related to mathematics?" "What can be done about achievements in mathematics and the mathematics curriculum?" Examples of activities in the literature (Akkaş et al., 2020; Tarhan et al., 2021) regarding the skills shown in Figure 1 were also given and discussions of these examples were held. Afterwards, the pre-service teachers were asked to prepare examples of related activities from the secondary school mathematics curriculum, focusing on their preferred grade levels and achievements and considering aspects of entrepreneurship skills education. For this assignment, the pre-service teachers were divided into groups and each group consisted of 5 people. The groups were determined by the pre-service teachers themselves. Group work was used because the pre-service teachers had not done any studies on entrepreneurship education before; therefore, group work provided an opportunity for them to exchange ideas with each other and come up with original activity examples. While preparing the activity 
samples, the pre-service teachers were asked to pay attention to the relevant aspects of entrepreneurship education according to the skills connected to mathematics teaching. After the preparation of the activity samples, a structured interview form consisting of open-ended questions about the lesson and about the activity examples was administered to the pre-service teachers to determine their views of the entrepreneurship education and mathematics teaching connection lessons and the activity examples they prepared after this course. The questions on the interview form addressed the pre-service teachers' views of aspects of entrepreneurship education and their ability to connect those aspects with mathematics teaching. With this goal, the questions on the interview form were as follows:

1) What did you know about "entrepreneurship education and its aspects" before receiving entrepreneurship education?

2) After receiving entrepreneurship education, how do you connect mathematics teaching with entrepreneurship education?

3) How do you plan to be beneficial to your students after receiving entrepreneurship education?

4) In the activity examples that you prepared, how did you determine the grade level and achievements you chose in the secondary school mathematics course in relation to the aspects of entrepreneurship education?

Each question on the interview form was presented to the pre-service teachers individually and the order of questions was the same for each pre-service teacher. The interviews lasted approximately 20 minutes. The interview form was also presented to two experts for their opinion. The final form was shaped according to their feedback. Interviews were audio-recorded and electronically saved.

\section{Data Analysis}

Content analysis was used in the analysis of the collected data. The analysis was carried out in three stages. First of all, the data obtained as audio recordings were analyzed and those analyses were checked by a person not involved in the research. The data were then coded by the researcher. The data were separately analyzed by a different researcher not involved in the research and $85 \%$ agreement was found between the codes that emerged. In the separate codings, the data and codes were considered again and were rearranged according to the consensus between the researchers. In the interview findings obtained as a result of the analysis of the qualitative data, the codes of Ö1, Ö2, Ö3..., Ö20 were used instead of the names of the pre-service teachers. Sections of the activity samples prepared by the participants as a group were also included in the findings, described as "Group 1, Group 2, Group 3, and Group 4 activity examples." 


\section{Ethics Committee Approval and Permission for the Research}

Ethics committee approval for this study was obtained from the Ethics Committee of Human Research in Social Sciences, Bolu Abant İzzet Baysal University, dated 01.06.2021 and numbered 2021/217.

\section{FINDINGS}

In this section, the findings that emerged as a result of the analysis of the data obtained in this study are presented.

\section{Findings for the first sub-problem}

Findings about what the pre-service mathematics teachers knew about "entrepreneurship education and its aspects" before receiving entrepreneurship education are given in Table 1.

\section{Table 1}

Pre-service teachers' knowledge of "entrepreneurship education and its aspects" before receiving entrepreneurship education

\begin{tabular}{lcc}
\hline Previous Knowledge & $\mathrm{f}$ & $\%$ \\
\hline I did not previously receive any entrepreneurship training. & 10 & 50 \\
I have never encountered or heard of entrepreneurship education and its & 6 & 30 \\
aspects. & & \\
I was not interested because I heard about entrepreneurship in social areas. & 4 & 20 \\
Total & 20 & 100
\end{tabular}

From the answers given by the pre-service mathematics teachers to this first question, it is seen that $50 \%$ of the pre-service teachers had not received previous entrepreneurship training. Thirty percent of the remaining 50\% stated that they had not encountered entrepreneurship education and its aspects before, and the other $20 \%$ stated that they were not interested even though they had heard of it, since they associated entrepreneurship with social fields. Accordingly, it is seen that none of the pre-service teachers had meaningful knowledge about entrepreneurship education and its aspects. Sample answers from the pre-service teachers regarding the replies shown in Table 1 are as follows:

"I've heard of the concept of entrepreneurship, but I don't know about education and its aspects. Frankly, I did not receive entrepreneurship training until this class, so I can't say anything..." (Ö3). 
"My roommate in the dormitory is studying to be a social studies teacher. I heard about entrepreneurship from one of their classes, but I had never connected it with mathematics, so I didn't ask and it didn't interest me..." (Ö11).

"I have never heard of entrepreneurship aspects..." (Ö18).

\section{Findings for the second and third sub-problems}

After the pre-service mathematics teachers were trained about entrepreneurship education, educational aspects, and how these different aspects could be connected with mathematics teaching, two parallel questions were asked. The first of these questions was "How do you connect mathematics teaching with entrepreneurship education after entrepreneurship education?" and the second was "How do you plan to be useful to your students after this training?" As a result of the analysis of the answers received from the pre-service teachers, the findings in Figure 2 and Table 2 were obtained.

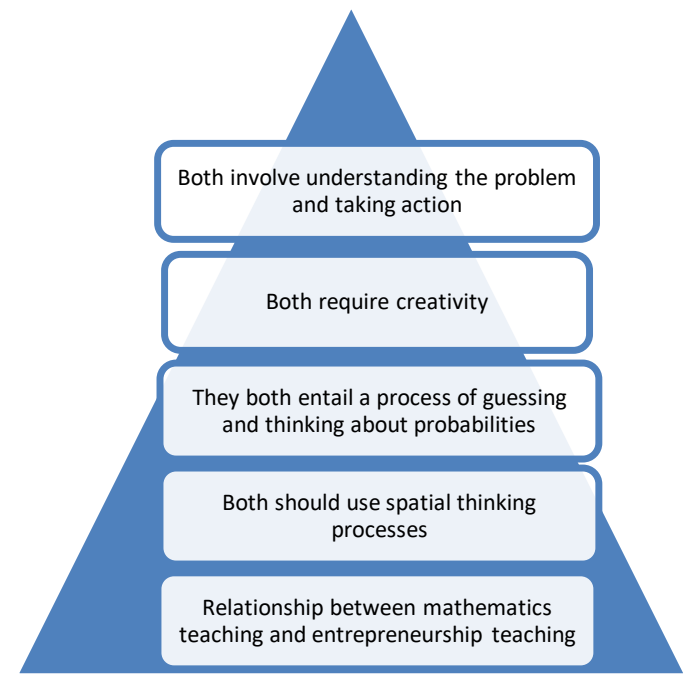

Figure 2. Pre-service teachers' diagrams of the relationship between mathematics teaching and entrepreneurship education

When Figure 2 is examined, the schematic categorization of the pre-service teachers' answers is seen. Since all 20 pre-service teachers said that they could connect mathematics teaching with entrepreneurship education after their education and more than one of these connection schemes was stated, the frequency table is not given here. For example, one pre-service teacher used problem-solving, creativity, and spatial thinking processes in explaining the connection. Below are answers received from some pre-service teachers in this regard:

"With the training, I learned things that I never thought of; of course, now I can relate it. For example, entrepreneurship starts with a business idea. In fact, this is like problemsolving in mathematics, understanding and defining the problem, or we call it workplace 
design in entrepreneurship, which requires spatial thinking skills when we look at it..." (Ö7).

"First of all, I would like to say that I got a lot out of the course because I learned how this skill, which I connect in social areas, would work with mathematics. As an example, I believe an entrepreneurial spirit should be creative and consider certain possibilities in advance. All of these actually exist in mathematics teaching. For example, we say 'newgeneration problems,' and they actually support creative and different thinking..." (Ö19).

When the pre-service teachers were asked how they planned to be beneficial to their students after this training, they gave answers parallel to those in Figure 2. The categories and frequencies of these answers are presented in Table 2.

Table 2

The plans of pre-service teachers for being beneficial to their students after entrepreneurship education

\begin{tabular}{lcc}
\hline Targeted Plans & $\mathrm{f}$ & $\%$ \\
\hline $\begin{array}{l}\text { To integrate it with new-generation questions and use it in the measurement- } \\
\text { evaluation process }\end{array}$ & 8 & 40 \\
$\begin{array}{l}\text { To exemplify it with real-life examples, using entrepreneurial activities in } \\
\text { lectures }\end{array}$ & 7 & 35 \\
To support students' different and creative thinking & 5 & 25 \\
Total & 20 & 100 \\
\hline
\end{tabular}

The prominent point seen in these answers was the process of "integrating with newgeneration questions" (40\%). For example:

Ö5: When I learned the aspects of connection and entrepreneurship education in mathematics teaching, a light shone in my mind.

A: How would you use it, can you explain?

Ö5: Well, we think of new-generation questions as different questions, but they are not different, they are questions that help to think differently. So, both to stimulate the entrepreneurial spirit of the student and to create common skills, such as creativity and guessing, I would create motivational questions and use them at the end of the lesson to evaluate them in the process.

A: How will you stimulate the entrepreneurial spirit in your lessons?

Ö5: As we learned, [by asking] "What would you do if it were you?" or "Do we offer alternatives?" "What if this happens?" 
As can be seen in the dialogue between the researcher and Ö5 given above, the preservice teacher explained that he will try to make students think differently and establish a link between mathematics and real life by using skills that are the basis of both mathematics teaching and entrepreneurship education.

Findings regarding the activity examples prepared by the groups

\section{Group 1}

Connections of mathematics teaching - entrepreneurship education aspects

Financing and cost calculation skills

Achievements

M.7.3.3.3. Calculates the area of the circle and circle segment.

M.6.3.5.1. Recognizes liquid measurement units and converts them to each other.

M.7.1.4. Ratios and proportions.

M.7.1.4.3. Examines real-life situations and decides whether two multiplicities are proportional

b) Directly proportional multiplicities are handled.

\section{Math Cafe}

Cansu, Merve, Yeşim, and Fatma go to the math cafe together. They order from the menu below.

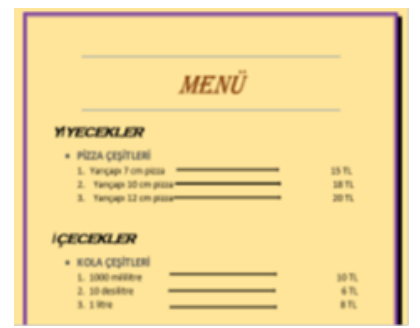

Cansu orders a pizza with a radius of $10 \mathrm{~cm}$ and 10 deciliters of Coke.

Yeşim orders a pizza with a radius of $12 \mathrm{~cm}$ and 1000 milliliters of coke.

Merve orders a pizza with a radius of $7 \mathrm{~cm}$ and 1 liter of coke.

Fatma orders a 12-cm pizza and a 10-dL Coke.

Which one ordered more economically?

Which two products should be chosen to make the most profitable order?

Were the orders given by Yeşim and Fatma different?

Did Merve or Cansu make a more cost-efficient order?

Figure 3. Group 1 activity assignment example 
When the activity example developed by Group 1 is examined, it is seen that both sixthyear and seventh-year achievements are utilized and these gains are connected with each other and with the entrepreneurial financing aspect of cost calculation skills. At the same time, it emphasized practical gains by calculating the circle area and converting the liquid measurement units to each other. It was aimed here to develop entrepreneurship skills in students with cost calculations by determining which products were more profitable and economical by establishing a ratio between products.

\section{Group 2}

Connecting mathematics teaching - entrepreneurship education aspects

Product design and production - Product design skill

Achievements

M.6.3.5.2. Relates liquid measurement units with volume measuring units.

Which one?

The packaging design is the design of the outer surface of a product for the brand's corporate identity and consumers. The design makes the material attractive. It arouses attention and gives a sense of belonging. The packaging and design represent the integration of form with design. Attractive designs increase sales.

Mr. Çağlar runs a cafeteria. In order to attract the attention and interest of the customers, he conducted research and decided to produce drinks with creative packaging designs that also allow for easier recycling.
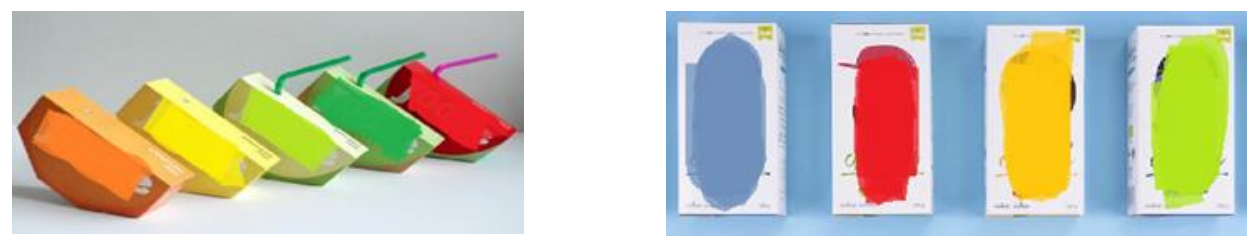

The packages that Mr. Cağlar will produce are in the form of rectangular prisms and the edge lengths are $5 \mathrm{~cm}, 10 \mathrm{~cm}$, and $10 \mathrm{~cm}$. Since Mr. Çağlar has 20 liters of beverage, how many designed packages should he produce?

If you were Mr. Çağlar, what kind of packaging would you design for drinks?

Figure 4. Activity example of Group 2

When the activity example developed by Group 2 is examined, it is seen that the achievement of connecting sixth-grade liquid measurement units with volume 
measurement units was used. While Group 2 prepared this question for this outcome, the question was connected with entrepreneurship product design and production aspect-product design skills. At the same time, Group 2, at the end of the assignment, pointed out that the entrepreneur must first do research and dominate the market in order to design and produce a product. They also mentioned that the designs made the product attractive and attracted attention. Therefore, they stated that the products designed by an entrepreneur should be remarkable and meet the demands. They stated that with this example of an activity, students can be taught entrepreneurial values such as being sensitive to the environment (as it contributes to recycling) and self-control.

\section{Group 3}

Connecting mathematics teaching - entrepreneurship education aspects

Investment - Networking skills/Problem posing and solving skills

Achievements

M.7.1.5.3. Makes calculations to increase or decrease a multiplicity by a certain percentage.

\section{Define Your Own Strategy}

Ahmet decided to launch a new venture and planned to retire from his job and establish a farm. In line with this plan, he researched the farm costs and got information about the types of cows he would keep on the farm.

He received information about four breeds of cows that can adapt to the climatic conditions of Turkey: Jersey, Holstein, Simental, and Brown Swiss cows. All of these cows have their own characteristics. Jersey cows produce 30 liters of milk per day. Holstein cows produce 50 liters of milk per day. Simmental cows produce 40 liters of milk per day. Brown Swiss cows produce 30 liters of milk per day. The price of a liter of milk is 3 TL.

Farms consist of 2 types:

\begin{tabular}{|l|l|l|l|l|}
\hline TYPE OF COW & JERSEY & HOLSTEIN & SIMENTAL & BROWN SWISS \\
\hline $\begin{array}{l}\text { Daily Milk } \\
\text { Production }\end{array}$ & $30 \mathrm{~L}$ & $50 \mathrm{~L}$ & $40 \mathrm{~L}$ & $20 \mathrm{~L}$ \\
\hline Cow Price & $8000 \mathrm{TL}$ & $12000 \mathrm{TL}$ & $10000 \mathrm{TL}$ & $6000 \mathrm{TL}$ \\
\hline
\end{tabular}

Our first farm, Abundance Farm, reduces the daily milk production of every cow on the farm by $10 \%$. Its price is $100,000 \mathrm{TL}$. 
Our second farm, Festival Farm, increases the daily milk production of each cow on the farm by $20 \%$. Its price is 200,000 TL.

\begin{tabular}{l|l|l}
\hline Farm Names & Prices & Production \\
\hline Abundance & $100,000 \mathrm{TL}$ & $-10 \%$ \\
\hline Festival & $200,000 \mathrm{TL}$ & $+20 \%$ \\
\hline
\end{tabular}

First strategy:

Ahmet buys Abundance Farm and fills it with equal numbers of Jersey and Holstein cows.

\section{Second strategy:}

Ahmet buys Festival Farm and buys Simental cows with $70 \%$ of his money and Brown Swiss cows with the remaining money.

Ahmet took out a loan of 300,000 TL from the bank for this venture. Ahmet wants to pay this loan back as soon as possible. Note: The monthly interest on 300,000 TL is $8 \%$.

How can Ahmet pay off his debt most quickly?

If you were to offer advice to Ahmet, what kind of strategy would you apply, other than these two ways, to pay off the debt in a shorter time?

Figure 5. Activity example of Group 3

When the activity example developed by Group 3 is examined, it is seen that the seventh-grade acquisition of "makes calculations to increase or decrease a multiplicity by a certain percentage" was used. As Group 3 prepared a question for this outcome, it was seen that the question was connected with the entrepreneurial investment aspect and networking skills/problem posing and solving skills. The purpose of this activity example was to have students establish a profit-loss connection and apply their own strategies according to their own perspectives by questioning the investment conditions in the situation based on the increase or decrease of the percentage of a multiplicity. At the end of Group 3's activity example, they stated that, with this question, they aimed to build students' decision-making skills and entrepreneurship research, development, and business method skills, along with mathematical reasoning skills.

\section{Group 4}

Connections of mathematics teaching - entrepreneurship education aspects

Business idea - Guessing ability/problem-solving ability

Achievements 
M.7.4.1.4. Displays data as a column, circle, or line graph and makes appropriate conversions between these representations.

M.5.3.1.1. Creates research questions that require data collection.

\section{WHERE CAN WE OPEN THE BOUTIQUE?}

Nazll, who is a housewife, and her friends decided to open a boutique in İstanbul thanks to KOSGEB, which supports women entrepreneurs. In order for this boutique to succeed, Nazlı conducted detailed research about which district she should open the boutique in, the population of the city, and whether she should open a boutique in an area with higher female or male density. Let's examine the graphics and help Nazlı decide.

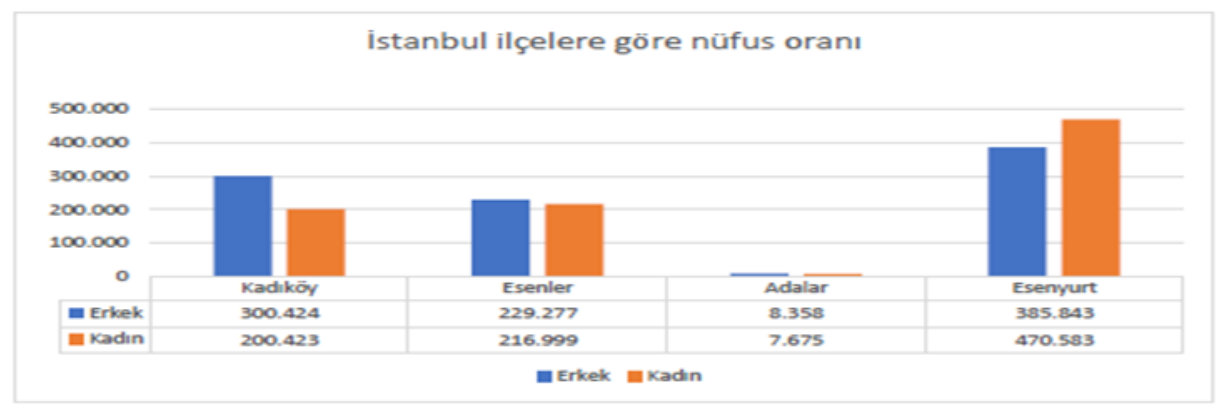

Let's examine the above population chart.

a) Do you think Nazlı should open a boutique in a place where the population is low or should she open it in a more crowded city. Why?

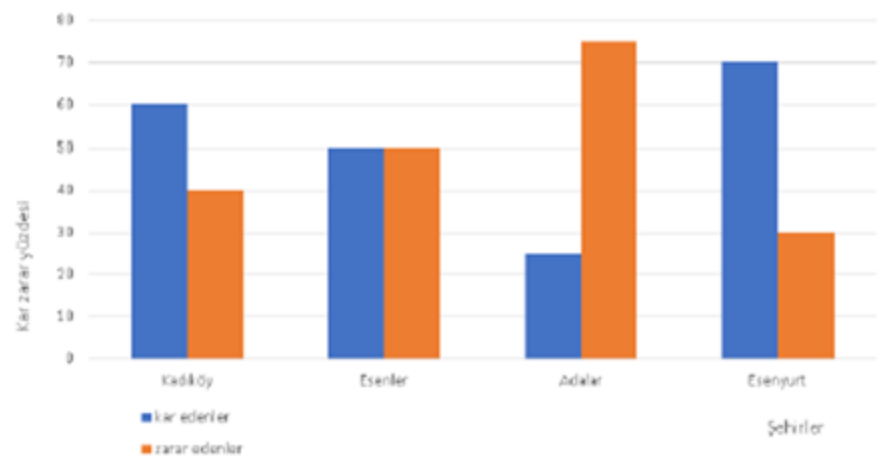

b) Can you convert the second graph into circle percentage graphs for each district separately so that Nazlı can see the profit and loss percentages better? Do you think it would be easier to express it with a column graph, or which other graph would you use?

c) In which city and for which gender should Nazlı open a boutique? State the reasons.

d) What other data do you think Nazlı should obtain in order to open a boutique? Collect the data related to the question you will ask and show it with a graphic of your choice 
(for example, which type of clothing is sold more, or how many competing boutiques are next to the boutique you will open).

Figure 6. Activity example of Group 4

When the activity example developed by Group 4 is examined, it is seen that both seventh-grade and fifth-grade achievements are utilized and these achievements are connected with each other and with the business idea aspect and estimation and problem-solving skills. In addition, Group 4 stated that while preparing this activity homework, they aimed to provide students with business plan and business design skills, as well as creative and innovative thinking skills.

In the activity samples prepared by all groups, the groups prepared questions about the entrepreneurship education aspects and the relevant skills of these aspects that can be connected with mathematics teaching, and these questions were compatible with both the achievements and the connection process.

\section{Findings for the fourth sub-problem}

After the preparation of the activity samples, interview question 4 was asked, regarding how the pre-service mathematics teachers determined the achievements they had chosen in the secondary school mathematics course for the aspects of entrepreneurship education in the activity samples they prepared. Based on the answers received from this question, the findings are presented in Table 3.

\section{Table 3}

The plans of pre-service teachers to be beneficial to their students after entrepreneurship education

\begin{tabular}{lcc}
\hline Targeted Plans & $\mathrm{f}$ & $\%$ \\
\hline $\begin{array}{l}\text { To integrate it with new-generation questions and use it in the measurement- } \\
\text { evaluation process. }\end{array}$ & 8 & 40 \\
$\begin{array}{l}\text { To exemplify it with real-life examples and entrepreneurial activity examples } \\
\text { in lectures. }\end{array}$ & 7 & 35 \\
To support students' different and creative thinking. & 5 & 25 \\
Total & 20 & 100
\end{tabular}

When Table 3 is examined, it is seen that most of the pre-service teachers (80\%) stated that while determining the class level and the achievement at that class level in the 
activity examples they prepared, they looked at their compatibility with the skills for entrepreneurship education aspects. Only one pre-service teacher stated that he agreed with whatever the majority of the group chose. Some of the answers from the preservice teachers are as follows:

"The priority for us is to look at what entrepreneurship education aspects we have learned and what the sub-skills are, and then consider the curriculum before us and connect it with which class and which achievement can be compatible and how questions can be written. We determined it this way as a group..." (Ö2).

"I usually use the grade level I like to study at, which is more like Grade 6. My learning area is clear, but I get more efficiency in the acquisitions when I prepare comfortable questions. When my group mates accepted my request, we didn't have any problems..." (Ö11).

\section{CONCLUSION, DISCUSSION AND RECOMMENDATIONS}

The aim of this study has been to examine examples of activities prepared by pre-service mathematics teachers for entrepreneurship education based on their knowledge of the aspects of entrepreneurship education and the achievements of this information in the secondary school mathematics curriculum. According to the research findings, thirdyear pre-service teachers participating in this research did not have prior knowledge about the concepts of entrepreneurship skills and entrepreneurship education aspects. In the study by Akkaş (2021), which examined the knowledge and images of pre-service primary school mathematics teachers regarding the concepts of entrepreneurship and entrepreneurship skills, it was stated that there were pre-service teachers who had never heard of these concepts, and the pre-service teachers who stated that they had heard of the concepts explained that they had heard of the concepts mostly in social areas. In this study, $20 \%$ of the pre-service teachers stated that they did not think about mathematics teaching because they connected the concept of entrepreneurship with social fields. Ay and Acar (2016) also stated in their study that pre-service teachers said that the courses that come to mind and are effective in gaining entrepreneurship skills are life sciences, social studies, and Turkish courses.

In this study, based on Coxford's (1995) definition of connection, the ability to relate in mathematics teaching was synthesized with the aspects of entrepreneurial skills. As a result, this different dimension of connection provided an opportunity for pre-service teachers to be creative in the assignments they prepared. When the group assignments given by the pre-service teachers were examined, it was seen that all groups prepared original assignments for different grade levels and achievements. Thus, it can be concluded that the education given by the researcher was in accordance with the definition determined by the NCTM (1989) that "the way to increase students' mathematical skills and learning is through their flexibility to approach situations from different angles and to make sense of the connections between these different approaches." In addition, connecting mathematics teaching and entrepreneurship skills, 
educating pre-service teachers about this connection dimension, and asking them to complete homework on this connection was done for the first time in the literature in this study. Although the aspects of entrepreneurship and entrepreneurship skills seem to be identified with the field of social sciences, it can also be included in mathematics teaching with its sub-dimensions such as creative thinking skills, problem-solving skills, and estimation skills. Thus, it is thought that if pre-service teachers learn to think differently and interpret the process differently, when they become teachers, they will give their students the opportunity to support these skills and they will support their students. For this reason, it is important to evaluate the "connection in mathematics teaching" course at the undergraduate level and similar field courses.

After the training given for the aspects of entrepreneurship education, the pre-service teachers' schemes of connecting entrepreneurship education and mathematics teaching were defined as "understanding the problem and taking action, creativity, estimation and the ability to think about possibilities, and spatial thinking skills." Similarly, in the study conducted by Gözübüyük (2008), the development of skills such as entrepreneurship, creativity, critical thinking, and reflective thinking were evaluated in parallel and it was shown that these skills are interrelated and important.

As Clegg et al. (2005) stated, with entrepreneurship education, students are expected to turn entrepreneurship education into practice. With this study, pre-service teachers were given the opportunity to design an example of a post-training activity and they were given the opportunity to put their entrepreneurship education into practice. At this point, it can be expected that pre-service teachers who start to receive entrepreneurship and entrepreneurship education from the first year of their undergraduate education will turn this education into practice in the teaching practice courses they take in their final year. In this sense, it can be suggested to include entrepreneurship training in other faculties than the Faculties of Economics, Administrative Sciences, and Business Administration, and especially in the Faculty of Education. In addition, as Solomon stated, the essence of entrepreneurship education should reflect reality (Solomon, 2007). Based on this point, former graduates who have achieved entrepreneurial success in different areas with the entrepreneurship education given at the university can be invited to the classroom environment and their experiences can be shared with pre-service teachers. Entrepreneurship and entrepreneurship skills concepts, whose place and importance are increasing day by day, should be included more in curricula, the achievements for entrepreneurship skills should be specified, and the designed activity examples should be given more space in textbooks. In addition, it is recommended that similar studies be carried out with more pre-service teachers who are taking the same course at other universities for comparison purposes. At the same time, the study can be repeated as a case study in order to evaluate the situation among pre-service teachers at different grade levels. 


\section{References}

Akkaş, E. N., Tarhan, M., \& Ayvaz, Ü. (2020). Gaining entrepreneurship skills with the activities designed related to primary school mathematics curriculum: The case of Turkey. Acta Didactica Napocensia, 13(2), 93-112. https://doi.org/10.24193/adn.13.2.7.

Akkaş, E. N. (2021). Knowledge and Images of Pre-service Elementary Mathematics Teacher About Entrepreneurship and Entrepreneurship Skills. Europen Journal of Studies, 8(2), 66-87. doi:10.46827/ejes.v8i2.3551

Ağca, V. (2007). Avrupa Birliğinin girişimcilik politikası ve Türkiye'ye yansımaları [Entrepreneurship policy of the European Union and its reflections on Turkey]. (Eds. M. Kurt and S. Bayraktaroğlu). Türkiye'de işletmecilikte yeni perspektifler. 169-194. Ankara: Gazi Kitabevi.

Ay S. T., \& Acar Ş. (2016). Views of classroom teachers about the acquisition of entrepreneurial skills. Electronic Journal of Social Science, 58, 960-976. doi: 10.17755/esosder.03138.

Bilge H., \& Bal V. (2012). Girişimcilik eğilimi: Celal Bayar Üniversitesi öğrencileri üzerine bir araștırma [Entrepreneurship tendency: A study on Celal Bayar University students]. Süleyman Demirel Üniversitesi Sosyal Bilimler Enstitüsü Dergisi, 2(16), 131148.

Bulut, Ç., \& Aslan, G. (2014). Üniversitelerde Girişimcilik Eğitimi [Entrepreneurship Education in Universities], Sosyal Ekonomik Araştırmalar Dergisi, 27, 1-20.

Clegg, S. R., Cunha, J. V., \& Cunha, M. P., (2002). Management Paradoxes: A Relational View, Human Relations, 55(5), 483-503.

Coxford, A. F. (1995). The Case for Connections. P. A. House and A.F. Coxford (Ed.), Connecting Mathematics across the curriculum, (ss. 3-12). Reston, VI: National Council of Teachers of Mathematics.

Çepni, S. (2012). Araştırma ve proje çalışmalarına giriş [Introduction to research and project work]. Trabzon: Celepler Matbaacllı.

Figel, J. (2006). Key competences for lifelong learning. Education and Training, http://ec.europa.eu/dgs/education_culture/publ/pdf/ll-learning/keycomp_en.pdf.

İşcan O., \& Kaygın E. (2011). Potansiyel girişimciler olarak üniversite öğrencilerininGirişimcilik eğilimlerini belirlemeye yönelik bir araştırma [A research to determine the entrepreneurship tendencies of university students as potential entrepreneurs]. Organizasyon ve Yönetim Bilimleri Dergisi, 3(2), 275-286.

Korkmaz O. (2012). Üniversite öğrencilerinin girişimcilik eğilimlerini belirlemeye yönelik bir araştırma: Bülent Ecevit Üniversitesi örneği [A study to determine the entrepreneurship tendencies of university students: The case of Bülent Ecevit 
University]. Afyon Kocatepe Üniversitesi İktisadi ve İdari Bilimler Fakültesi Dergisi, 14(2), 209-226

Lee S. M., \& Peterson S. (2000). Culture, entrepreneurial orientation, and global competitiveness. Journal of World Business, 35, 401-416. https://doi.org/10.1016/S1090-9516(00)00045-6.

Milli Eğitim Bakanlı̆̆ı, (2005). Matematik Dersi Öğretim Programı [Mathematics Curriculum]. T.C. Millî Eğitim Bakanlığı, Ankara, Turkiye.

National Council of Teachers of Mathematics [NCTM]. (1989). Curriculum and Evaluation Standards for School Mathematics. Reston, VA: Author.

Pan V. L., \& Akay C. (2015). Eğitim fakültesi öğrencilerinin girişimcilik düzeylerinin çeşitli değişkenler açısından incelenmesi [Examining the entrepreneurship levels of education faculty students in terms of various variables]. Education Sciences, 9(6),125-138.

Solomon, G. (2007). An Examination of Entrepreneurship Education in the United States, Journal of Small Business and Enterprise Development, 14(2), 168-182.

Tarhan, M. (2019). Girişimcilik pedagojisine giriş [Introduction to entrepreneurship pedagogy]. Pegem Akademi Yayıncılık.

Tarhan, M., Akkaş, E. N., \& Ayvaz, Ü. (2021). Gaining entrepreneurship skills in mathematics education: the middle school mathematics course curriculum of Turkey, International Journal of Mathematical Education in Science and Technology, 52(6), 122.

Uygun M., Mete S., \& Güner E., (2012). Genç Girişimci Adayların Girişimcilik Eğilimi ve Girişimcilik Özellikleri Arasındaki İlişkiler [The Relationships Between Entrepreneurial Tendency and Entrepreneurial Characteristics of Young Entrepreneur Candidates]. Organizasyon ve Yönetim Bilimleri Dergisi, 2(4), 145-156

Yüksek Öğretim Kurumu [YÖK] (2018). İlköğretim Matematik Öğretmenliği Lisans Programı [Elementary Mathematics Teaching Undergraduate Program]. https://www.yok.gov.tr/Documents/Kurumsal/egitim_ogretim_dairesi/Yeni-

Ogretmen-Yetistirme-Lisans-

Programlari/Ilkogretim_Matematik_Lisans_Programi.pdf.

Wang C., \& Wong P. (2004). Entrepreneurial Interest in University Students in Singapore. Technovation, 24(2), 163-172. https://doi.org/10.1016/S01664972(02)00016-0. 
Ethics committee approval for this study was obtained from the Ethics Committee of Human Research in Social Sciences, Bolu Abant İzzet Baysal University, dated 01.06.2021 and numbered 2021/217.

Statement of Contribution of Researchers to the Article:

1st author contribution rate: $100 \%$

Conflict of Interest Statement:

There is no conflict of interest.

Statement of Financial Support or Acknowledgment:

No financial support was received from any institution for this study. 


\title{
Matematik Öğretmen Adaylarının Girişimcilik Eğitimi Unsurlarına Yönelik Hazırladıkları Etkinlik Örneklerinin İncelenmesi*
}

\author{
Elif Nur AKKAŞ ${ }^{* *}$
}

\begin{abstract}
Öz. Bu çalışmanın amacı, matematik öğretmen adaylarının girişimcilik eğitimi unsurlarına yönelik bilgilerini ve bu bilgilere yönelik ortaokul matematik öğretimi programındaki kazanımları temel alarak, girişimcilik eğitimine yönelik hazırladıkları etkinlik örneklerinin incelenmesidir. Ulusal ve uluslararası literatürde, matematik eğitiminde girişimcilik becerisi ve bu beceriyi geliştirmeye yönelik çalışmalar oldukça az sayıdadır. Ayrıca ortaokul matematik dersi öğretim program kazanımları ve bu kazanımlara uygun hazırlanmış uygulama örnekleri bulunmamaktadır. Çalışmanın katılımcılarını, 3. Sınıf lisans dersi olan "matematik öğretiminde ilişkilendirme” dersini alan ve araştırmaya gönüllü 20 öğretmen adayı oluşturmaktadır. Öğretmen adaylarına iki hafta, yaklaşık 40 dakikalık, dört ders, toplam 160 dakika "girişimcilik, girişimcilik becerisi nedir?, matematikle nasıl ilişkilendirilir? ve matematik dersi öğretim programında yer alan kazanımlara yönelik uygulama örnekleri neler yapılabilir?" konuları anlatılmış ve araştırmacının kendi çalışmasından uygulama örnekleri vermiştir. Bu anlatımın ardından, öğretmen adaylarına ödev verilmiştir. Araștırmanın verilerini ödev verileri ve ödev analizlerinden sonra bireysel olarak yapılan görüşmelerdeki ses kayıt çözümlemeleri oluşturmaktadır. Veriler içerik analizi ile analiz edilmiștir.
\end{abstract}

Anahtar Kelimeler: Matematik öğretiminde ilişkilendirme, girişimcilik, girişimcilik eğitim unsurları, etkinlik örnekleri, matematik öğretmen adayları

\footnotetext{
* Bu çalışma için etik kurul izni 01.06.2021 tarih ve 2021/217 sayılı Bolu Abant İzzet Baysal Üniversitesi Sosyal Bilimlerde İnsan Araștırmaları Etik Kurulu'ndan alınmıștır.

** Orcid ID: https://orcid.org/0000-0002-8286-8203, Dr. Öğr. Üyesi, Bolu Abant İzzet Baysal Üniversitesi, Türkiye, elifnurakdogan@hotmail.com
} 


\section{GİRIŞ}

Endüstriyel toplum çağından, bilgi ve teknoloji çağına geçilen şu günlerde, bireylerde iş gücü yerine, akıllı, mantıklı ve pratik zekaya sahip insan profili öne çıkmaktadır. Bu anlamda çağın hılı değişimlerine ayak uydurabilen, girişimci bireylerin yetiştirilmesinde en önemli unsur eğitimdir. Eğitim, bireylerde girişimcilik ve girişimcilik becerisinin kazandırılması ve gelişmesindeki en büyük yardımcı faktörlerden biridir. Bu yönde girişimci faaliyetlerin arttırılması için gerçekleştirilen girişimcilik eğitimleri de, her ülkenin kendine özgü kültürel bağlamı çerçevesinde bireylere aktarılmaktadır (Lee ve Peterson, 2000). Türkiye'de girişimcilik ve girişimcilik becerisi kavramları 2005 yılından itibaren Milli Eğitim Bakanlığı'nın gündeminde olmuştur. Milli Eğitim Bakanlığı (2005) girişimciliği, "empati kurma, insan ilişkilerinde uyumlu davranışlar gösterebilme, plan yapma, planı uygulayabilme, risk alma ve herhangi bir alanda gerek duyulan ürünü fark etme" olarak tanımlayarak, bu kavramı eğitim sürecine uyarlamıştır. Girişimci bireyler yetiştirmek için öncelikle girişimcilik becerisi ele alınmalıdır. Girişimcilik becerisi bireyin duygu ve düşüncelerini eyleme geçirme, hedeflenen amaca ulaşmak için plan yapabilme, süreci yönetebilme, risk alan,yaratıcı, yenilikçi becerilerini gerçekleştirmek için gerekli bir beceri olarak tanımlanmaktadır (Figel, 2006, 3-12). Bu beceriyi kazandırmak için de çeşitli eğitimler verilmektedir. Verilen girişimcilik eğitimlerinde asıl amaç; kişiye hem girişimcilik bilincinin ve hem de girişimcilik becerisinin kazandırılmasıdır (Ağca, 2007). Ancak ulusal ve uluslararası literatür incelendiğinde, daha çok sosyal bilimler, iktisadi ve idari bilimler, mühendislik gibi alanlarda girişimcilik eğitimlerine yönelik çalışıldığı tespit edilmiştir (Wang ve Wong, 2004; İşcan ve Kaygın, 2011; Uygun, vd., 2012; Bilge ve Bal, 2012; Korkmaz, 2012; Pan ve Akay, 2015). Girişimcilik becerisini kazandırmak için verilen eğitimlerde, temelde bireylere kazandırılması gereken beş eğitim unsuru vardır. Bunlar; "iş fikri, finansman, ürün tasarımı- üretimi, tanıtım-pazarlama, yatırım" unsurları olarak adlandırılmaktadır (bknz. Ek 1). Bu unsurlar, kendi içlerinde becerilere ayrılmaktadır. Girişimcilik eğitimi sürecinde, öğrencilerin iş fikirlerinin oluşturulmasında yardımcı olacak bilgileri içeren konular iş fikri; iş fikrinin hayata geçirilmesinden yatırım sürecinin sonuna kadar geçen süreç içerisindeki temel düşünceler finansman; iş fikrinin finansmanı sağlandıktan sonra ürünü ait tasarım süreci, ürün tasarımı ve üretimi; ürüne ait pazar ve pazarlama olanaklarının belirlenmesi, tanıtım ve pazarlama; ve son olarak hayata geçirilen iş fikrinin, gerçekleştirilen ürün veya hizmetin üretim olanaklarının ve sürekliliğinin sağlanması ise yatırım unsurları olarak tanımlanmaktadır (Tarhan, 2019).

Girişimcilik eğitimini bir süreç olarak ifade eden Fayolle (2006:702), girişimcilikle ilgili tutum, beceri ve kişisel niteliklerin kazandırılmasını içeren bir pedagojik program ya da eğitim sürecine işaret etmektedir. $\mathrm{Bu}$ yönde girişimcilik ve girişimcilik becerisine yönelik eğitimlerin üniversitelerin eğitim fakültelerinde de verilmesi uygun olacaktır. Girişimcilik eğitimlerinde öğrencilerin, girişimcilik eğitimini pratiğe dönüştürmeleri beklenmektedir (Clegg, vd., 2005). Girişimcilik eğitiminin katı, kuralcı, tamamen sonuç odaklı bir eğitim olmasından ziyade, eğitimi alan kişilerin yetenek ve becerilerinin açığa 
çıkmasına fırsat tanıması önemlidir (Bulut, Aslan, 2014). Bu yönde girişimcilik ve girişimcilik becerisine yönelik eğitim fakültesinde verilecek derslerin, öğretmen adaylarının düşünme süreçlerini harekete geçireceği, aynı zamanda atandıkları okullarda öğrencilerine farklı girişimler yaratmada başarı sağlayacağı düşünülebilir.

\section{Araştırmanın amacı}

Bu çalışmayla, öğretmen adaylarının henüz mesleğe atılmadan, matematik dersi öğretim programında girişimcilik ve girişimcilik becerisi kavramlarını ne kadar tanıdıkları da belirlenmiş olacaktır. Ayrıca fakültede girişimcilik adında daha önceden bir ders aldılarsa, bu eğitimin öğretmen adaylarına katkısı incelenecektir. Daha önceden bir ders almadılarsa da, araştırmacı tarafından verilen eğitim sonrası, yaptıkları etkinlikler incelenecektir. $\mathrm{Bu}$ incelemelerden yola çlkarak, eğitim sürecindeki gereksinimler belirlenecek ve girişimcilik ve girişimcilik becerisinin günlük yaşamda ve matematik eğitiminde daha sık kullanılmasının önü açllacaktır. Ayrıca bu çalışmanın, öğretmen eğitiminde girişimcilik eğitimi ve matematik öğretimi ile ilişkilendirme konusunda yürütülecek gelişimsel araştırmalara yol gösterici nitelikte olacağı düşünülmektedir. Bu çalışmanın amacı, matematik öğretmen adaylarının girişimcilik eğitimi unsurlarına yönelik bilgilerini ve bu bilgilere yönelik ortaokul matematik öğretimi programındaki kazanımları temel alarak, girişimcilik eğitimine yönelik hazırladıkları etkinlik örneklerinin incelenmesidir. Bu amaç doğrultusunda çalışmada, aşağıdaki sorulara cevap aranmıştır:

1) Girişimcilik eğitimi almadan önce matematik öğretmen adayları "girişimcilik eğitimi ve unsurlarına" yönelik neler biliyor?

2) Matematik öğretmen adayları, girişimcilik eğitimi sonrasında, matematik öğretimi ile girişimcilik eğitimini nasıl ilişkilendiriyor?

3) Matematik öğretmen adayları aldıkları eğitim sonucunda öğrencilerine nasıl faydalı olmayı planlıyor?

4) Matematik öğretmen adayları hazırladıkları etkinlik örneklerinde, ortaokul matematik dersinde seçmiş oldukları kazanımları, girişimcilik eğitim unsurlarına yönelik nasıl belirlediler?

\section{Araştırmanın önemi}

Eğitim Fakültelerinde, matematik öğretmenliği anabilim dalında verilen güncel dersler incelendiğinde, girişimcilik ve girişimcilik becerisine yönelik en uygun ders "matematik öğretiminde ilişkilendirme” dersi olarak düşünülebilir. Çünkü bu dersin temelinde "ilişkilendirme süreci" vardır. Coxford (1995), bu ilişkilendirme sürecini genel olarak "matematikteki farklı konuları bağ kurmada kullanılabilecek çok geniş fikirler ve süreçler bütünü" olarak tanımlamıştır. Bu tanımdan yola çıkarak, "matematik eğitimi ve girişimcilik becerisi" farklı konularla bağ kurmak ve yeni fikirler üretmek amacıyla birbiriyle ilişkilendirilebilir (Akkaş, vd. 2020; Tarhan, vd. 2021). Ayrıca girişimcilik eğitimlerinde bireylerin, girişimcilik eğitimini pratiğe dönüştürmeleri beklenmektedir (Clegg, vd., 2005). Bunun yanı sıra girişimcilik eğitiminin katı, kuralcı ve sonuç odaklı bir 
eğitim olmasından ziyade, eğitimi alan kişilerin yetenek ve becerilerinin açığa çıkmasına fırsat tanıması önemlidir (Bulut, Aslan, 2014). Tüm bu sonuçlar dikkate alındığında, matematik öğretimi ve girişimcilik eğitiminin ilişkilendirilmesiyle öğretmen adaylarının etkinlik hazırlamaları, hem öğretmen adayları için yeni ve yaratıcı bir deneyim olması hem de öğretmen adaylarının düşünme süreçlerini harekete geçireceği için ilerde öğrencilerine farklı girişimler yaratmada başarı sağlayacağı düşünülebilir. Belirtilen nedenlerden ötürü bu araştırmanın literatüre önemli katkıları olacağına inanılmaktadır. Öncelikle literatürde, matematik öğretmen adaylarının girişimcilik eğitim unsurlarına yönelik hazırladıkları etkinlikleri inceleyen başka bir çalışmaya rastlanılmamıştır.

\section{YÖNTEM}

\section{Araştırmanın Modeli}

$\mathrm{Bu}$ araştırmada betimsel araştırma yöntemlerden özel durum çalışması kullanılmıştır. Özel durum çalışmalarında, belirlenmiş bir olay, bir grup ile özel bir durumla ilgili çalışılarak elde edilen verilerin ayrıntıları; sebep-sonuç ilişkileri incelenmeye çalışılarak gerçekleştirilir (Çepni, 2012).

\section{Katılımcılar}

Araştırmanın katılımcılarını, bir eğitim fakültesinde öğrenim görmekte olan, lisans 3. Sınıf matematik öğretmen adaylarından, $10 \mathrm{klz} 10$ erkek olmak üzere, toplam 20 öğretmen adayı oluşturmaktadır. Öğretmen adaylarının lisans 3. Sınıf seçilmelerinin nedeni, hazırlanacak etknlik örneklerinin "matematik öğretiminde ilişkilendirme" dersine uygun olması ve bu dersin lisans 3. Sınıf dersi olmasıdır. Matematik öğretiminde ilişkilendirme dersinin seçilme nedeni ise, matematiği girişimcilik ve girişimcilik becerisi ile ilişkilendirmek ve böylece bu derste öğretmen adaylarının bu kavramları ne denli öğrendiklerini, hazırladıkları etkinlik ödevleri üzerinden görmektir. Bu nedenlerden ötürü katılımcıların seçiminde nitel araştırma amaçlı örnekleme yöntem türlerinden, ölçüt örnekleme yöntemi kullanılmıştır. Katılımcıların araştırmaya gönüllü olmalarına dikkat edilmiştir.

\section{Uygulama Süreci ve Veri Toplama Aracı}

$\mathrm{Bu}$ araştırma "matematik öğretiminde ilişkilendirme" dersini alan ve bu derste araştırmaya gönüllü olan 20 öğretmen adayı ile gerçekleştirilmiştir. Bu ders zorunlu bir ders olmakla birlikte, matematik öğretmenliği lisans 3. Sınıf, 6. Dönem dersi olarak verilmektedir. Dersin içerik tanımı "Kavramlar ve işlemler arasında ilişki kurma; matematiksel kavram ve kuralları farklı gösterim biçimleri ile ifade etme; farklı matematik kavramlarını birbiri ile ilişkilendirme; matematiği diğer derslerle ilişkilendirme; matematiği günlük hayatla ilişkilendirme" (YÖK, 2018) şeklinde belirlenmiştir. Bu tanımdan ve Coxford (1995) ilişkilendirme tanımından yola çıkarak girişimcilik eğitim unsurları ve alt becerileri, matematik öğretiminde matematiksel becerilere göre uyarlanmış ve matematik öğretmen adaylarına verilen eğitimde bu ilişkilendirme süreci kullanılmıştır. Bu uyarlama sürecinde, Akkaş, vd. (2020) ve Tarhan, 
vd. (2021) ilkokul/ortaokul matematik dersi öğretim programından hareketle girişimcilik becerisinin kazandırılması çalışmalarından yararlanılmış ve öğretmen adaylarına verilen eğitimde Şekil 1'deki süreç kullanılmıştır.

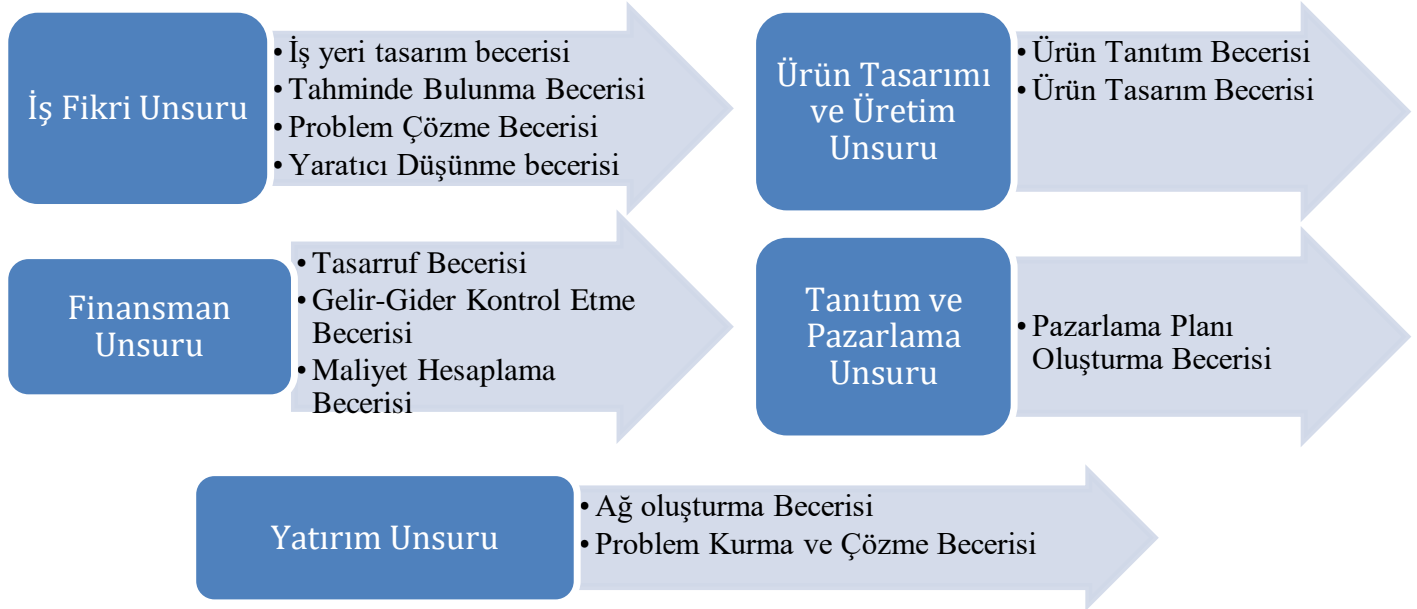

Şekil 1. Girişimcilik Becerisine Ait Beş Unsur ve Bu Unsurlara Ait Becerilerden, Matematik Öğretimiyle İlişkilendirilen Beceriler

Dersin kapsamında, iki hafta, yaklaşık 40 dakikalık, dört ders, toplam 160 dakika "girişimcilik, girişimcilik becerisi nedir?, matematikle nasıl ilişkilendirilir? ve matematik dersi öğretim programında yer alan kazanımlara yönelik uygulama örnekleri neler yapılabilir?" konuları anlatılmış ve şekil 1'de ilişkilendirilen becerilere yönelik literatürdeki (Akkaş, vd, 2020; Tarhan, vd., 2021) etkinlik örnekleri verilmiş ve bu örnekler üzerinden tartışmalar yapılmıştır. Daha sonra öğr etmen adaylarından ortaokul matematik dersi öğretim programından, istedikleri sınıf düzeyi ve kazanımlarını içeren, girişimcilik becerisi eğitim unsurlarına ait ilişkilendirilmiş etkinlik örnekleri hazırlamaları istenmiştir. Bu ödev çalışmasında öğretmen adayları gruplar halinde ayrılmış ve her grup 5 kişiden oluşmuştur. Gruplar öğretmen adayları tarafından belirlenmiştir. Grup çalışması yapılmasının istenme amacı ise, öğretmen adaylarının daha önceden girişimcilik eğitimine dair bir çalışma yapmamış olmamaları ve bu nedenle birbirleri ile fikir alışverişi yapmalarına ve orijinal etkinlik örneklerinin çıkmasına fırsat sağlanmasıdır. Öğretmen adaylarından etkinlik örneklerini hazırlarken, girişimcilik eğitim unsurlarının, matematik öğretimiyle ilişkilendirilen becerilerine göre hazırlamalarına dikkat etmeleri istenmiștir. Etkinlik örneklerinin hazırlanmasından sonra, öğretmen adaylarına verilen girişimcilik eğitimi ve matematik öğretimi ilişkilendirme dersleri ve bu ders sonrasında hazırladıkları etkinlik örneklerine yönelik öğretmen adaylarının görüşlerini tespit etmek amacıyla öğretmen adaylarına "derse dair" ve "etkinlik örneklerine dair" açık uçlu sorulardan oluşan yapılandırılmış görüşme formu uygulanmıştır. Görüşme formu sorularında; öğretmen adaylarının girişimcilik eğitimi unsurları ve bu unsuları matematik öğretimiyle ilişkilendirme becerilerine 
yönelik görüşleri derinlemesine belirlenmeye çalışılmıştır. Bu yönde görüşme formunda, araştırmanın amacına yönelik sorulan sorular aşağıdaki gibi belirlenmiştir;

1) Girişimcilik eğitimi almadan önce "girişimcilik eğitimi ve unsurlarına” yönelik neler biliyordunuz?

2) Girişimcilik eğitimi aldıktan sonrasında, matematik öğretimi ile girişimcilik eğitimini nasıl ilişkilendiriyorsunuz?

3) Girişimcilik eğitimi aldıktan sonra öğrencilerinize nasıl faydalı olmayı planlıyorsun?

4) Hazırladığınız etkinlik örneklerinde, ortaokul matematik dersinde seçmiş olduğunuz sınıf seviyesi ve kazanımları, girişimcilik eğitim unsurlarına yönelik nasıl belirlediniz?

Görüşme formundaki her soru, öğretmen adaylarına bireysel olarak sunulmuş ve her soru sırası her öğretmen adayı için aynı olmuştur. Görüşmeler yaklaşık 20 dakika sürmüştür. Görüşme formu, iki uzman görüşüne sunulmuştur. Gelen dönütlere göre son şekli belirlenmiştir. Görüşmelerde ses kaydı yapılmış ve elektronik ortamda kaydedilmiştir.

\section{Verilerin Analizi}

Toplanan verilerin analizinde içerik analizi tekniği kullanılmıştır. Analiz üç aşamada gerçekleştirilmiştir. Öncelikle ses kaydı olarak elde edilen verilerin çözümlemesi yapılmış ve çözümlemeler araştırma dışından bir kişiye kontrol ettirilmiştir. Daha sonra veriler araştırmacı tarafından kodlanmıştır. Ayrı olarak veriler araştırma dışından farklı bir araştırmacıya da analiz ettirilmiş ve ortaya çıkan kodlar arasında \%85 uyum tespit edilmiştir. Ayrı çıkan kodlarda, verilere ve kodlara tekrar dönülmüş, araştırmacılar arasında varılan fikir birliği sonucuna göre yeniden düzenlenmiștir. Nitel verilerin analizi sonucunda elde edilen görüşme bulgularda öğretmen adaylarının isimleri yerine “Ö1, Ö2...” gibi kodlar kullanılmıştır. Ayrıca katılımcıların grup halinde hazırladıkları etkinlik örneklerinden kesitlere de, bulgularda, "grup 1, grup 2,...grup 4 etkinlik örnekleri" şeklinde betimsel bir şekilde yer verilmiştir.

\section{Araştırmanın Etik Kurul ve İzni}

Araştırma sürecinin başlaması için gerekli etik kurul izinleri, 01.06.2021 tarih ve 2021/217 sayll Bolu Abant İzzet Baysal Üniversitesi Sosyal Bilimlerde İnsan Araştırmaları Etik Kurulu'ndan alınmıștır.

\section{BULGULAR}

Bu bölümde araştırma da elde edilen verilerin analizi sonucunda ortaya çıkan bulgular sunulmaktadır.

\section{Birinci alt probleme yönelik bulgular}

Çalışmada, matematik öğretmen adaylarının, girişimcilik eğitimi almadan önce , "girişimcilik eğitimi ve unsurlarına" yönelik neler bildiklerine dair bulgular, tablo 1 de verilmektedir. 
Tablo 1

Öğretmen adaylarının girişimcilik eğitimi öncesi, "girișimcilik eğitimi ve unsurlarına" dair görüşleri

\begin{tabular}{lcc}
\hline Görüşler & $\mathrm{f}$ & $\%$ \\
\hline Girişimcilik eğitimi almadım. & 10 & 50 \\
Girișimcilik eğitimi ve unsurları ile daha önce hiç karşılaşmadım/ & 6 & 30 \\
duymadım. & & \\
Girişimciliği sosyal alanlarda duyduğum için ilgilenmedim. & 4 & 20 \\
\hline Toplam & 20 & 100
\end{tabular}

Matematik öğretmen adaylarının birinci alt probleme ait verdikleri cevaplardan, öğretmen adaylarının yüzde ellisi, girişimcilik eğitimi almadığını belirtmiştir. Kalan yüzde ellinin, yüzde otuzu ise, girişimcilik eğitimi ve unsurları ile daha önceden karşılaşmadığını, diğer yüzde yirmi ise girişimciliği sosyal alanlarla ilişkilendirdiği için, duymuş olsa da ilgilenmediğini belirtmiştir. Bu görüşlerden yola çlkarak, öğretmen adaylarının hiçbirinin girişimcilik eğitimi ve unsurlarına dair bilgi sahibi olmadığı görülmektedir. Tablo 1'deki görüşlere yönelik öğretmen adaylarının örnek cevapları şu şekildedir;

"Girişimcilik kavramını duydum ama eğitimi ve unsurlarını bilmiyorum. Açıkçası bu sınıfa kadar girişimcilik eğitimi almadım o nedenle bir şey diyemeyeceğim...”(Ö3).

"Yurtta oda arkadaşım sosyal bilgiler öğretmenliğinde okuyor. Onların bir dersinde girişimciliği duydum ama ben hiç matematikle iliş̧ilendirmemiştim, ee öyle olunca da sormadım ve ilgimi çekmedi..." (Ö11).

“Girişimcilik unsurları diye bir şey hiç duymadım...” (Ö18).

\section{İkinci ve üçüncü alt probleme yönelik bulgular}

Çalışmada matematik öğretmen adaylarına girişimcilik eğitimi, eğitim unsurları ve bu unsurların matematik öğretimiyle nasıl ilişkilendirilebileceğine yönelik eğitim verildikten sonra, öğretmen adaylarına birbirine paralel iki soru sorulmuştur. Bu sorulardan ilki "girişimcilik eğitimi sonrasında öğretmen adayları matematik öğretimi ile girişimcilik eğitimini nasıl ilişkilendiriyor?” ve bir diğeri de “öğrencilerine bu eğitim sonrası nasıl faydalı olmayı planlıyorlar?”. Öğretmen adaylarından alınan cevapların analizi sonucunda şekil 2 ve tablo 2'deki bulgular elde edilmiştir. 


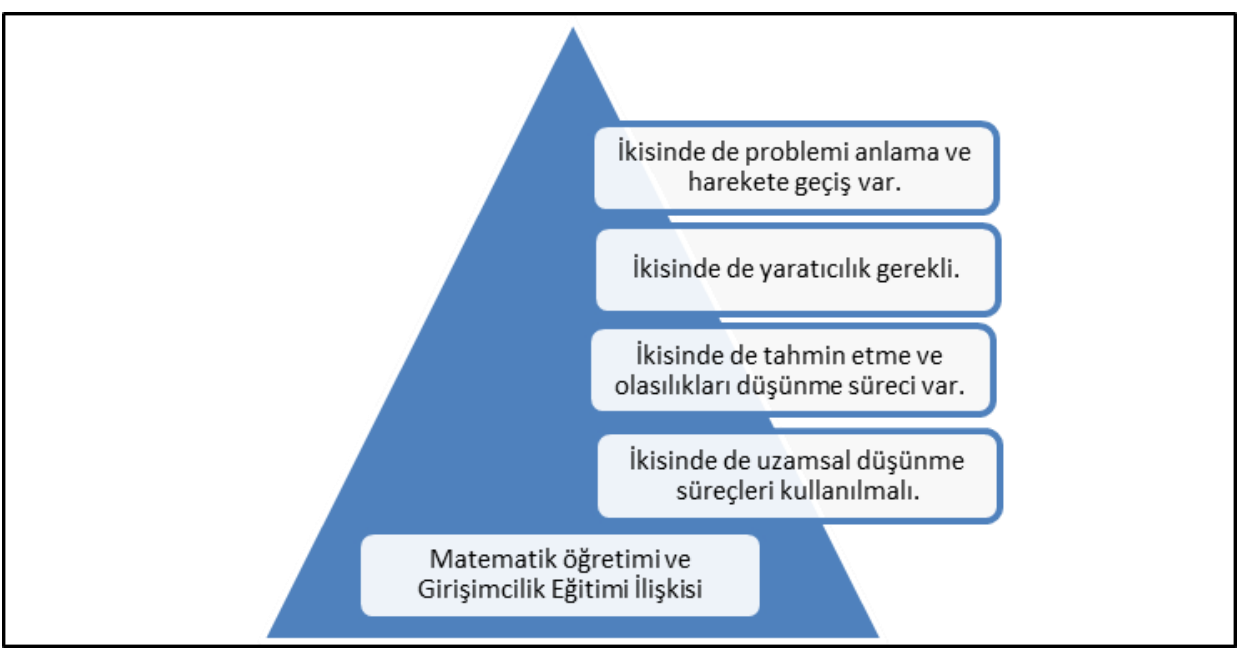

Şekil 2. Öğretmen adaylarının matematik öğretimi ve girişimcilik eğitimini ilişkilendirme şemaları

Şekil 2 incelendiğinde, öğretmen adaylarının cevaplarının şemasal kategorisi görülmektedir. Yirmi öğretmen adayının tamamı aldıkları eğitim sonrası matematik öğretimi ile girişimcilik eğitimini ilikilendirebileceklerini ve bu ilişkilendirme şemalarının birden fazlasını söyledikleri için, frekans tablosu verilmemiştir. Örneği bir öğretmen adayı ilişkilendirme açıklamasında, hem problem çözme hem yaratıcılık hem de uzamsal düşünme süreçlerini de kullanmıştır. Aşağıda bazı öğretmen adaylarından alınan cevaplara yer verilmektedir.

"Eğitimden sonra hiç aklımda olmayan şeyler öğrendim, elbette artık ilişkilendirebilirim. Mesela iş fikri ile başllyor girişimcilik. Bu aslında matematikte problem çözümünde, problemi anlama tanımlama gibi, ya da iş yeri tasarımı diyoruz girişimcilikte, bu da baktığımızda uzamsal bir düşünme becerisi istiyor...." (Ö7).

“Öncelikle dersten çok verim aldığımı söylemek istiyorum. Çünkü sosyal alanlarda ilişkilendirdiğim bu beceri matematikle nasıl olurmuş onu öğrendim. Örnek olarak, girişimci bir ruhun yaratıcı olması ve önceden bazı olasılıkları düşünmesi gerektiğine inanıyorum. Tüm bunlar aslında matematik öğretiminde de var. Mesela yeni nesil problemler diyoruz, aslında yaratıcı farklı düşünmeyi destekliyor bunlarda..." (Ö19).

Bu cevaplardan sonra, öğretmen adaylarına bu eğitim sonrası öğrencilerine nasıl faydalı olacakları konusunda neler planladıkları sorulduğunda da, şekil 2 ye paralel cevaplar gelmiştir. Bu cevaplara yönelik oluşturulan kategoriler ve frekans tablosu, tablo 2'de sunulmaktadır. 
Tablo 2

Girişimcilik eğitimi sonrasında öğretmen adaylarının öğrencilerine faydalı olma planları

\begin{tabular}{lcc}
\hline Hedeflenen Planlar & f & $\%$ \\
\hline Yeni nesil sorulara entegre edip ölçme-değerlendirme sürecinde kullanmak. & 8 & 40 \\
$\begin{array}{l}\text { Ders anlatımında, gerçek yaşamla örneklendirmek, öğrenilen girişimcilik } \\
\text { etkinlik örneklerini kullanmak. }\end{array}$ & 7 & 35 \\
$\begin{array}{l}\text { Öğrencilerin farklı ve yaratıcı düşünmelerini desteklemek. } \\
\text { Toplam }\end{array}$ & 5 & 25 \\
\hline
\end{tabular}

Bu cevaplarda öne çıkan detay, "yeni nesil sorulara entegre" süreci olmuştur (\%40). Örneğin;

Ö5: Matematik öğretiminde ilişskilendirme ve girişimcilik eğitimi unsurlarını öğrendiğimde, aklımda, ben öğretmen olduğumda bunu öğrencilerime yeni nesil soru dediğimiz soru tiplerinde kullanırdım ışı̆̆ı parladı hemen.

A: Nasıl kullanırdın, açar misın?

Ö5: Şöyle, ...yeni nesil soruları farklı soru diye düşünüyoruz ama farklı değil, farklı düşünmeye yardımcı sorular. E haliyle hem öğrencinin girişimci ruhunu canlandırmak hem de ortak beceriler işte hani öğrendik yaratıcılık, tahmin gibi bunları harekete geçirici sorular oluşturur ve ders sonunda onları süreçte değerlendirmek için kullanırdım.

A: Soruda girişimci ruhu nasıl canlandıracaksın?

Ö5: Yine öğrendiğimiz gibi, "sen olsan ne yapardın?" ya da "alternatifler sunuyoruz ya?" bu olsa ne olur?, bu olsa ne olur?, Pazar payı gibi düşünecek yani, esnaflık, işçilik ya da üretimci gibi....

\section{A: Anladım, teşekkürler...}

Yukarıda verilen araştırmacı ve Ö5 arasında geçen diyalogta da görüldüğü üzere, öğreten adayı planlarında, hem matematik öğretiminde hem de girişimcilik eğitiminin temelinde olan becerileri kullanarak öğrencilerin farklı düşünmelerini ve matematik ile hayat, gerçek yaşam arasında bir bağ kurdurmaya çalışacağından da bahsetmektedir.

\section{Grupların hazırladığı etkinlik örneklerine yönelik bulgular}

\section{Grup 1}

Matematik öğretimi- girişimcilik eğitim unsurları ilişkilendirme

Finansman- Maliyet Hesaplama Becerisi

Kazanimlar

M.7.3.3.3. Dairenin ve daire diliminin alanını hesaplar.

M.6.3.5.1. Sıvı ölçme birimlerini tanır ve birbirine dönüştürür.

M.7.1.4. Oran ve Orantı 
M.7.1.4.3. Gerçek hayat durumlarını inceleyerek iki çokluğun orantılı olup olmadığına karar verir.

b) Doğru orantılı çokluklar ele alınır.

\section{Matematik Kafe}

Cansu, Merve, Yeşim ve Fatma beraber matematik kafeye gidiyorlar. Aşağıdaki menüden siparişlerini veriyorlar.

Cansu, yarıçapı $10 \mathrm{~cm}$ pizzadan ve 10 desilitrelik koladan sipariş veriyor.

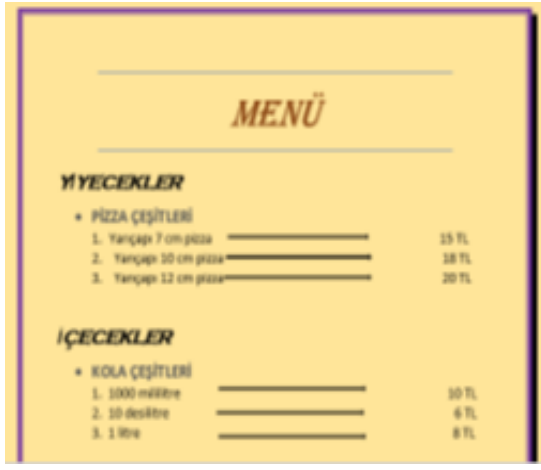

Yeşim, yarıçapı $12 \mathrm{~cm}$ pizzadan ve 1000 mililitrelik koladan sipariş veriyor.

Merve, yarıçapı $7 \mathrm{~cm}$ pizzadan ve 1 litrelik koladan sipariş veriyor.

Fatma, yarıçapı $12 \mathrm{~cm}$ pizzadan ve 10 desilitrelik koladan sipariş veriyor.

Buna göre;

Hangisi daha ekonomik sipariş vermiştir?

En karlı siparişi vermek için hangi iki ürün seçilmeliydi?

Yeşim ile Fatma'nın verdiği sipariş farklı mıdır?

Merve ile Cansu'dan hangisi karlı bir sipariş vermiştir?

Şekil 3. Grup 1 etkinlik ödev örneği

Grup 1 tarafından geliștirilen etkinlik örneği incelendiğinde, hem 6. Sınıf hem de 7. Sınıf kazanımlarından faydalanıldığı ve bu kazanımların hem birbiriyle hem de girişimcilik finansman unsuru- maliyet hesaplama becerisi ile ilişkilendirildiği görülmektedir. Aynı zamanda hem daire alanı hesaplama hem de sıvı ölçme birimlerini birbirine dönüştürme yaparak iki kazanımın da alıştırmasını yapmaktadırlar. Ürünler arasında oran orantı kurarak hangi ürünün daha karlı, daha ekonomik olduğunu belirleyerek de maliyet hesabı ile öğrencilerde girişimcilik becerisini geliştirmek amaçlanmıştır.

\section{Grup 2}

Matematik öğretimi- girişimcilik eğitim unsurları ilişkilendirme

Ürün tasarımı ve üretim- Ürün tasarım becerisi

Kazanım 
M.6.3.5.2. Sıvı ölçme birimlerini hacim ölçme birimleri ile ilişkilendirir.

\section{Hangisi Olsun?}

Ambalaj tasarımı, bir ürünün dış yüzeyinin marka kurumsal kimliğine ve tüketicisine yönelik tasarlanmasıdır. Tasarım, malzemeyi çekici kılar. Dikkat uyandırır, aidiyet hissettirir. Ambalaj ve tasarım, formun tasarımla bütünleşmesidir. Dikkat çekici tasarımlar satışları arttırır.

Çağlar Bey kafeterya işletmektedir. Müşterilerin dikkatini ve ilgisini çekebilmek için bir araştırma yapmış ve geri dönüşüme de katkısı olan yaratıcı ambalaj tasarımlı içecekler üretmeye karar vermiştir.
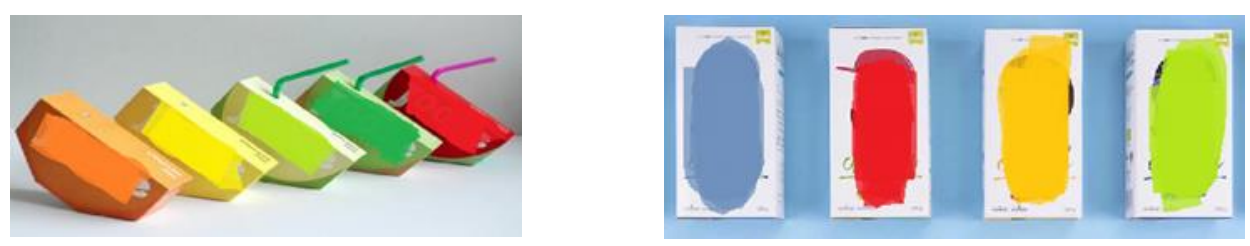

Çağlar Bey'in üreteceği ambalajlar dikdörtgenler prizması şeklinde olup ayrıt uzunlukları $5 \mathrm{~cm}, 10 \mathrm{~cm}$ ve $10 \mathrm{~cm}$ 'dir. Çağlar Bey 'in 20 litre içeceği olduğuna göre kaç tane tasarımlı ambalaj üretmesi gereklidir?

Çağlar Bey'in yerinde olsanız içecekler için nasıl bir ambalaj tasarlardınız?

Şekil 4. Grup 2 etkinlik örneği

Grup 2 tarafından geliştirilen etkinlik örneği incelendiğinde, 6. Sınıf sıvı ölçme birimlerini hacim ölçme birimleriyle ilişkilendirme kazanımının kullanıldığı görülmektedir. Grup 2 bu kazanıma yönelik soru hazırlarken, soruyu girişimcilik ürün tasarımı ve üretim unsuru- ürün tasarım becerisi ile ilişkilendirdiği görülmektedir. Aynı zamanda grup 2 ödev sonunda, girişimcinin, ürün tasarlamak ve üretmek için öncelikle araştırma yapması ve pazara hakim olması gerektiğine dikkat çekerek, yapılan tasarımların ürünü çekici kılıp ve dikkat uyandırdığından bahsetmiştir. Bu yüzden girişimcinin tasarladığı ürünlerin dikkat çekici ve talepleri karşılayıcı nitelikte olması gerektiğini belirtmişlerdir. Bu etkinlik örneği ile öğrencilere çevreye duyarlı olma (geri dönüşüme katkısı olduğu için) ve öz kontrol sahibi olma gibi girişimci değerlerinde kazandırılabileceğini belirtmişlerdir.

\section{Grup 3}

Matematik öğretimi- girişimcilik eğitim unsurları ilişkilendirme Yatırım- Ağ oluşturma becerisi/ Problem kurma ve çözme becerisi Kazanım: 
M.7.1.5.3. Birçokluğu belirli bir yüzde ile arttırmaya veya azaltmaya yönelik hesaplamalar yapar.

\section{Kendi Stratejini Kendin Belirle}

Ahmet Bey yeni bir girişim yapmaya karar vermiş ve işinden emekli olup bir çiftlik kurmayı planlamış. Bu plan doğrultusunda çiftlik maliyetlerini araştırmış ve çiftlik içerisinde besleyeceği ineklerin türleri hakkında bilgi edinmiştir.

Türkiye'nin iklim şartlarına uyum sağlayabilen dört cins inek hakkında bilgi almıştır bunlar: Jersey, Holstein, Simental ve Brown Swiss cinsi ineklerdir. Bu ineklerin hepsinin kendi içerisinde özellikleri bulunmaktadır. Jersey ineği günlük $30 \mathrm{~L}$ süt üretmektedir. Holstein ineği günlük 50 L süt üretmektedir. Simental ineği 40 L süt üretmektedir. Brownn Swiss cinsi inek ise günlük 30 L süt üretmektedir. Sütün litre fiyatı 3 TL'dir.

\begin{tabular}{l|l|l|l|l}
\hline CINSS & JERSEY & HOLSTEİN & SİMENTAL & BROWN SWISS \\
\hline GÜNLÜK SÜT ÜRETIMİ & $30 \mathrm{~L}$ & $50 \mathrm{~L}$ & $40 \mathrm{~L}$ & $20 \mathrm{~L}$ \\
& & & & \\
\hline İNEK FIYYATI & $8.000 \mathrm{TL}$ & $12.000 \mathrm{TL}$ & $10.000 \mathrm{TL}$ & $6.000 \mathrm{TL}$ \\
\hline
\end{tabular}

Çiftlikler ise 2 türden oluşmaktadır bunlar:

Birinci çiftliğimiz bolluk çiftlik, çiftlikte bulunan her ineğin günlük süt üretimini \%10 azaltmaktadır. Fiyatı 100 bin TL'dir.

İkinci çiftliğimiz şenlik çiftlik, çiftlikte bulunan her ineğin günlük süt üretimini $\% 20$ arttırmaktadır. Fiyatı 200 bin TL'dir.

\begin{tabular}{l|l|l}
\hline ÇİFTLIK İSIMLERİ & FIYATLARI & VERIM \\
\hline Bolluk & $100.000 \mathrm{TL}$ & $-\% 10$ \\
\hline Şenlik & $200.000 \mathrm{TL}$ & $+\% 20$ \\
\hline
\end{tabular}

1.Yol:

Ahmet Bey Bolluk çiftliğini satın alarak içerisini eşit sayıda Jersey ve Holstein inek cinsleri ile dolduruyor.

2.Yol:

Ahmet Bey Şenlik çiftliğini satın alarak kalan parasının \%70’i ile Simental ve artan parası ile de Brown Swiss inek cinslerini alıyor.

Ahmet Bey bu girişim için bankadan 300.000 TL kredi çekmiştir. Ahmet Bey bu krediyi en kısa sürede ödemek istiyor. Not: 300.000 TL'nin aylık faizi \%8'dir.

Ahmet Bey hangi yolu izlerse daha kısa sürede borcunu kapatabilir? 
Siz Ahmet Bey'e bir fikir verecek olsaydınız borcu daha kısa sürede kapatmak için bu iki yoldan farklı olarak nasıl bir strateji uygulardınız?

Şekil 5. Grup 3 etkinlik örneği

Grup 3 tarafından geliştirilen etkinlik örneği incelendiğinde, 7. Sınıf "bir çokluğu belirli bir yüzde ile arttırmaya veya azaltmaya yönelik hesaplamalar yapar" kazanımının kullanıldığı görülmektedir. Grup 3 bu kazanıma yönelik soru hazırlarken, soruyu girişimcilik yatırım unsuru- ağ oluşturma becerisi/ problem kurma ve çözme becerisi ile ilişkilendirdiği görülmektedir. Bu etkinlik örneği ile amaçlanan; bir çokluğun yüzdesinin arttırılıp azaltılması çözümlenerek oluşan durum genelinde öğrencilerin kâr zarar ilişkisi kurmaları ve yatırım şartlarını sorgulayarak bakış açılarına göre kendi stratejilerini uygulayabilmeleridir. Grup 3 etkinlik örneği sonunda, bu soruyla, öğrencilerin karşılaştıkları durumlara, matematiksel muhakeme becerisiyle birlikte karar verme becerisi ve girişimciliğin araştırma, geliştirme, iş yöntemi becerilerinin kazandırılmasını da hedeflediklerini belirtmişlerdir.

\section{Grup 4}

Matematik öğretimi- girişimcilik eğitim unsurları ilişkilendirme

İş fikri- Tahminde bulunma becerisi/problem çözme becerisi

M.7.4.1.4. Verileri sütun, daire veya çizgi grafiği ile gösterir ve bu gösterimler arasında uygun olan dönüşümleri yapar.

M.5.3.1.1. Veri toplamayı gerektiren araștırma soruları oluşturur.

\section{BUTIIĞİ NEREYE AÇSAK?}

Ev Hanımı olan Nazlı Hanım ve arkadaşları birlikte çalışmayan kadın girişimcilere destek veren KOSGEB sayesinde İstanbul'da bir butik açmaya karar vermişlerdir. Nazlı Hanım bu butiğin tutması için butiği hangi ilçede açması gerektiği, şehrin nüfusu ya da kız yoğunlukta mı erkek yoğunlukta mı bir butik açması gerektiği ile ilgili detaylı bir araştırma yapmıştır. Grafikleri inceleyip Nazlı Hanıma yardımcı olalım.

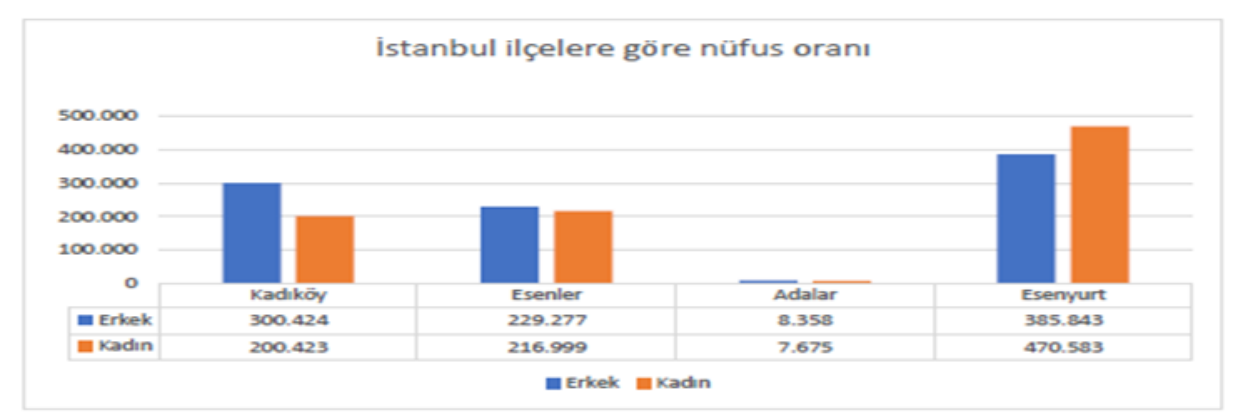


Yukarıdaki nüfus sütun grafiği ve tabloya dökülmüş halini inceleyelim.

a)Sizce Nazlı Hanım nüfusun az olduğu bir yerde mi butik açmalıdır yoksa daha kalabalık bir şehirde mi açmalıdır nedenleriyle açıklayınız?

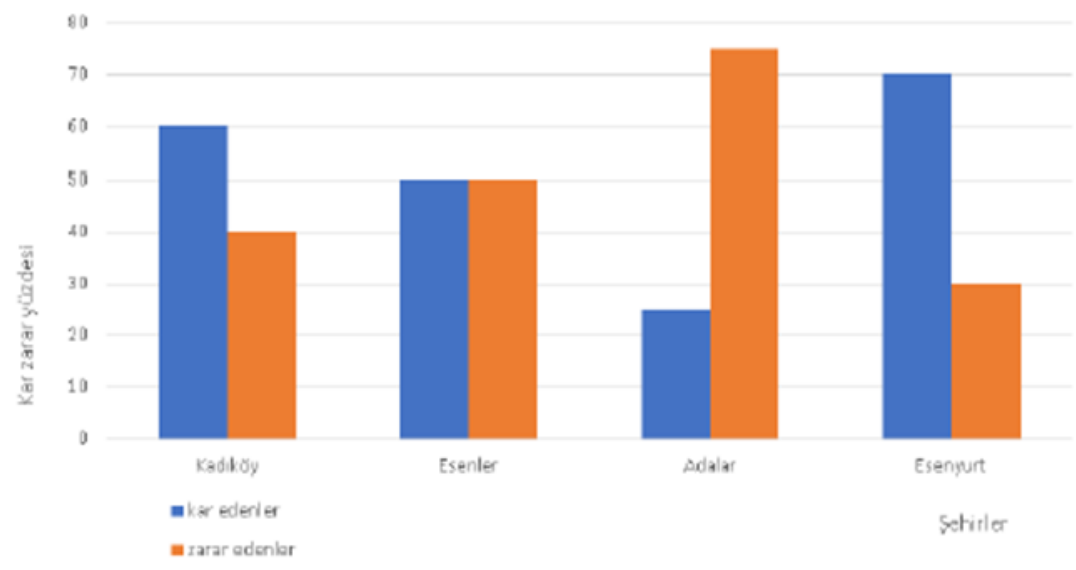

b) İkinci grafiği Nazlı hanımın kar - zarar yüzde oranlarını daha iyi görebilmesi için her bir ilçeyi ayrı ayrı daire yüzde grafiklerine çevirebilir misiniz sizce burada sütun grafiği ile ifade etmek mi daha kolay ya da siz olsaydınız hangi grafiği kullanırdınız?

c) Nazlı Hanım sizce hangi şehirde ve hangi cinsiyete yönelik bir butik açmalıdır? nedenleriyle birlikte ifade ediniz.

d) Nazlı Hanım butik açmak için sizce başka hangi verileri araştırmalı? Soracağınız soru ile ilgili verileri toplayıp istediğiniz bir grafikle gösteriniz (örneğin hangi kıyafet türü daha çok satılıyor, ya da açacağınız butiğin yanında rakip butik ne kadar var gibi)

Şekil 6. Grup 4 etkinlik örneği.

Grup 4 tarafından geliștirilen etkinlik örneği incelendiğinde, hem 7. Sınıf hem de 5. Sınıf kazanımlarından faydalanıldığı ve bu kazanımların hem birbiriyle hem de iş fikri unsuru- tahminde bulunma, problem çözme becerisi ile ilişkilendirildiği görülmektedir. Ayrıca grup 4 bu etkinlik ödevini hazırlarken, öğrenciye iş planı ve iş tasarımı becerisi, yaratıcı ve yenilikçi düşünme becerileri kazandırılmayı hedeflediğini belirtmiştir.

Tüm gruplar tarafından hazırlanan etkinlik örneklerinde, grupların, girişimcilik eğitim unsurları ve bu unsurların matematik öğretimi ile ilişkilendirilebilecek becerilerine yönelik sorular hazırladıkları ve bu soruların hem kazanımlarla hem de ilişkilendirme süreciyle uyumlu olduğu görülmektedir.

\section{Dördüncü alt probleme yönelik bulgular}

Etkinlik örneklerinin hazırlanmasından sonra, matematik öğretmen adaylarının hazırladıkları etkinlik örneklerinde, ortaokul matematik dersinde seçmiş oldukları kazanımları, girişimcilik eğitim unsurlarına yönelik nasıl belirledikleri yönelik görüşme 
sorusu (görüşme sorusu 4) sorulmuştur. Bu sorudan alınan cevaplar doğrultusunda Tablo 3' deki bulgular elde edilmiştir.

Tablo 3

Girişimcilik ĕgitimi sonrasında öğretmen adaylarının öğrencilerine faydalı olma planları

Hedeflenen Planlar

f $\%$

Yeni nesil sorulara entegre edip ölçme-değerlendirme sürecinde kullanmak. 840

Ders anlatımında, gerçek yaşamla örneklendirmek, öğrenilen girişimcilik $7 \quad 35$ etkinlik örneklerini kullanmak.

Öğrencilerin farklı ve yaratıcı düşünmelerini desteklemek. $5 \quad 25$ Toplam

Tablo 3 incelendiğinde, öğretmen adaylarının çoğu (\%80), hazırladıkları etkinlik örneklerinde, sınıf seviyesi ve bu sınıf seviyesindeki kazanımı belirlerken, girişimcilik eğitim unsurlarındaki becerilerle uyumuna baktıklarını belirtmişlerdir. Yalnızca bir öğretmen adayı, grup çoğunluğu neyi seçtiyse ona uyduğunu belirtmiştir. Öğretmen adaylarından gelen cevaplardan bazıları aşağıdaki şekildedir;

"Bizim için öncelikli olan öğrendiğimiz girişimcilik eğitim unsurları neler ve alt becerileri neler ona bakmak, ardından müfredatı önümüze açıp, hangi sınıf ve hangi kazanımla uyumlu olabilir, nasıl soru yazılabilir ilişkilendirmek, biz grup olarak bu şekilde belirledik..." (Ö2).

"Ben çalışmayı sevdiğim sınıf seviyesini kullanırım genelde, bu da daha çok 6. Sınıf. Öğrenme alanım bellidir ama kazanımlarda da yine rahat soru hazırladığım kazanımlarda daha verim alıyorum. Grup arkadaşlarımda benim isteğimi kabul edince sıkıntı yaşamadık, ben böyle belirledim..." (Ö11).

\section{SONUÇ, TARTIŞMA VE ÖNERİLER}

$\mathrm{Bu}$ çalışmanın amacı, matematik öğretmen adaylarının girişimcilik eğitimi unsurlarına yönelik bilgilerini ve bu bilgilere yönelik ortaokul matematik öğretimi programındaki kazanımları temel alarak, girişimcilik eğitimine yönelik hazırladıkları etkinlik örneklerinin incelenmesidir. Araştırma bulgularına göre, araştırmaya katılan 3. sınıf öğretmen adaylarının, girişimcilik becerisi ve girişimcilik eğitimi unsurları kavramlarına yönelik bilgi sahibi olmadıkları görülmektedir. Akkaş (2021) tarafından ilköğretim matematik öğretmen adaylarının girişimcilik ve girişimcilik becerisi kavramlarına yönelik bilgi ve imajlarını inceleyen çalışmada, bu kavramları hiç duymayan öğretmen adaylarının olduğu ve duyduğunu belirten öğretmen adaylarının da, kavramlar daha çok sosyal alanlarda duyduklarını belirttikleri ifade edilmiştir. Bu çalışmada da öğretmen adaylarının \%20 si, girişimcilik kavramını sosyal alanlarla ilişkilendirdikleri için 
matematik öğretimi ile düşünmediklerini belirtmişlerdir. Selanik Ay ve Acar (2016) da yapmış oldukları çalışmada, öğretmen adaylarının girişimcilik becerisini kazandırmada etkili olan ve akla gelen dersleri, Hayat Bilgisi, Sosyal Bilgiler ve Türkçe dersleri olarak söylediklerini belirtmişlerdir.

$\mathrm{Bu}$ çalışmada, Coxford (1995) ilişkilendirme tanımından yola çıkılarak matematik öğretiminde ilişkilendirme becerisi, girișimcilik becerisi unsurlarıyla sentezlenmiştir. Bu farklı ilişkilendirme boyutu sonuç olarak, öğretmen adaylarının hazırladıkları ödevlerde yaratıcı olmalarına yönelik bir fırsat sunmuştur. Öğretmen adaylarının verdikleri grup ödevleri incelendiğinde, tüm grupların, farklı sınıf seviyesi ve kazanımlara yönelik, orijinal ödevler hazırladıkları görülmüştür. Böylece araştırmacı tarafından verilen eğitimin, NCTM (1989) tarafından belirlenen "öğrencilerin matematik becerilerini ve öğrenmelerini arttırmanın yolu, onların durumlara farklı açlarda yaklaşacak esnekliğe sahip olmalarından ve bu farklı yaklaşımlar arasındaki ilişkileri anlamlandırmalarından geçmektedir" tanıma uygun olduğu sonucu çıkarılabilir. Ayrıca matematik öğretimi ve girişimcilik becerisini ilişkilendirmek ve öğretmen adaylarını bu ilişkilendirme boyutunda eğiterek, onlardan bu ilişkilendirmeye yönelik ödev istemek, literatürde ilk kez bu çalışmada gerçekleştirilmiştir. Girişimcilik ve girişimcilik becerisi unsurları sosyal bilimler alanıyla özdeşleşmiş gibi görünse de özellikle yaratıcı düşünme becerisi, problem çözme becerisi ve tahminde bulunma becerisi gibi alt boyutlarıyla matematik öğretiminde de yer alabilir sonucu, bu araştırmayla görülmektedir. Böylece öğretmen adaylarının farklı düşünme ve süreci farklı yorumlamayı öğrenmeleriyle, öğretmen olduklarında, öğrencilerinde bu becerileri desteklemelerine firsat verecekleri, öğrencilerini destekleyecekleri düşünülmektedir. $\mathrm{Bu}$ nedenle lisans düzeyinde «matematik öğretiminde ilişkilendirme» dersi ve bu derse benzer alan derslerinin süreçte değerlendirilmesi önemlidir.

Girişimcilik eğitimi unsurlarına yönelik verilen eğitimden sonrası, öğretmen adaylarının girişimcilik eğitimi ve matematik öğretimini ilişkilendirme şemaları, ortak dört başlık "problemi anlama ve harekete geçme, yaratıcılık, tahmin ve olasılıkları düşünme beceri süreci ve uzamsal düşünme becerisi” olarak tanımlanmıştır. Benzer şekilde Gözübüyük (2008) tarafından yapılan çalışmada, girişimcilik, yaratıcılık, eleştirel düşünme ve yansıtıcı düşünme gibi becerilerin gelișimi paralel değerlendirilmiş ve bu becerilerin birbiriyle ilişkili ve önemli olduğu gösterilmiştir.

Clegg vd., (2005) belirttiği gibi girişimcilik eğitimi ile öğrencilerin girişimcilik eğitimini pratiğe dönüştürmeleri beklenmektedir. Bu çalışma ile öğretmen adaylarına verilen eğitim sonrası etkinlik örneği tasarlamalarına fırsat verilerek, öğretmen adaylarının girişimcilik eğitimini pratiğe dökmelerine fırsat sağlanmıştır. Bu noktada lisans 1.sınıftan itibaren girişimcilik ve girişimcilik eğitimi verilmeye başlanan öğretmen adaylarının, son sınıfta gittikleri öğretmenlik uygulaması derslerinde bu eğitimi pratiğe dönüştürmeleri beklenebilir. Bu anlamda İktisat, İdari Bilimler ve İşletme Fakülteleri dışında kalan Eğitim fakültesi başta olmak üzere, diğer fakültelerde de girişimcilik eğitimlerinin programa alınması düşünülebilir. Ayrıca Solomon' un belirttiği gibi 
girişimcilik eğitiminin özü, gerçeği yansıtmalıdır (Solomon, 2007). Bu tanımdan yola çıkarak üniversitede verilen girişimcilik eğitiminde, girişimci başarı göstermiş, farklı yerlerde başarı sağlamış eski mezunlar sınıf ortamına davet edilebilir ve tecrübeleri öğretmen adaylarıyla paylaşılabilir. Gün geçtikçe yeri ve önemi artan girişimcilik ve girişimcilik becerisi kavramları, öğretim programlarında daha fazla yer almalı, bu noktada girişimcilik becerisine yönelik kazanımlar özellikle belirtilmeli ve tasarlanmış etkinlik örneklerine ders kitaplarında daha çok yer verilmelidir. Ayrıca bu çalışmanın, karşılaştırma amacıyla başka üniversitelerde bu ders kapsamında, dersi alan, daha fazla öğretmen adayıyla gerçekleştirilmesi önerilmektedir. Aynı zamandan farklı sınıf seviyelerinde öğretmen adaylarındaki durumu değerlendirmek açısından, durum çalışması olarak da çalışma tekrarlanabilir.

\section{Kaynaklar}

Akkaş, E. N., Tarhan, M. ve Ayvaz, Ü. (2020). Gaining entrepreneurship skills with the activities designed related to primary school mathematics curriculum: The case of Turkey. Acta Didactica Napocensia, 13(2), 93-112. https://doi.org/10.24193/adn.13.2.7.

Akkaş, E. N. (2021). Knowledge and Images of Pre-service Elementary Mathematics Teacher About Entrepreneurship and Entrepreneurship Skills. Europen Journal of Studies, 8(2), 66-87. doi:10.46827/ejes.v8i2.3551

Ağca, V. (2007). Avrupa Birliğinin girişimcilik politikası ve Türkiye'ye yansımaları. (Ed. M. Kurt ve S. Bayraktaroğlu). Türkiye'de işletmecilikte yeni perspektifler. 169-194. Ankara: Gazi Kitabevi.

Ay S. T. ve Acar Ş., (2016). Views of classroom teachers about the acquisition of entrepreneurial skills. Electronic Journal of Social Science, 58, 960-976. doi: 10.17755/esosder.03138.

Bilge H. ve Bal V. (2012). Girişimcilik eğilimi: Celal Bayar Üniversitesi öğrencileri üzerine bir araştırma. Süleyman Demirel Üniversitesi Sosyal Bilimler Enstitüsü Dergisi, 2(16), 131-148.

Bulut, Ç. ve Aslan, G. (2014). Üniversitelerde Girişimcilik Eğitimi, Sosyal Ekonomik Araştırmalar Dergisi, 27, (1-20).

Clegg, S. R., Cunha, J. V. ve Cunha, M. P., (2002). Management Paradoxes: A Relational View, Human Relations, 55(5), 483-503.

Coxford, A. F. (1995). The Case for Connections. P. A. House and A.F. Coxford (Ed.), Connecting Mathematics across the curriculum, (ss. 3-12). Reston, VI: National Council of Teachers of Mathematics.

Çepni, S. (2012). Araştırma ve proje çalışmalarına giriş. Trabzon: Celepler Matbaacılık. 
Figel, J. (2006). Key competences for lifelong learning. Education and Training. http://ec.europa.eu/dgs/education_culture/publ/pdf/ll-learning/keycomp_en.pdf.

İşcan O. ve Kaygın E. (2011). Potansiyel girişimciler olarak üniversite öğrencilerininGirişimcilik eğilimlerini belirlemeye yönelik bir araştırma. Organizasyon ve Yönetim Bilimleri Dergisi, 3(2), 275-286.

Korkmaz 0. (2012). Üniversite öğrencilerinin girişimcilik eğilimlerini belirlemeye yönelik bir araştırma: Bülent Ecevit Üniversitesi örneği. Afyon Kocatepe Üniversitesi Íktisadi ve İdari Bilimler Fakültesi Dergisi, 14(2), 209-226

Lee S. M. ve Peterson S. (2000). Culture, entrepreneurial orientation, and global competitiveness. Journal of World Business, 35, 401-416. https://doi.org/10.1016/S1090-9516(00)00045-6.

Milli Eğitim Bakanlı̆̆ı, (2005). Matematik Dersi Öğretim Programı. T.C. Millî Eğitim Bakanlığı, Ankara, Turkiye.

National Council of Teachers of Mathematics [NCTM]. (1989). Curriculum and Evaluation Standards for School Mathematics. Reston, VA: Author.

Pan V. L. ve Akay C., (2015). Eğitim fakültesi öğrencilerinin girişimcilik düzeylerinin çeşitli değişkenler açısından incelenmesi. Education Sciences, 9(6), 125-138.

Solomon, G. (2007). An Examination of Entrepreneurship Education in the United States, Journal of Small Business and Enterprise Development, 14(2), 168-182.

Tarhan, M. (2019). Girişimcilik pedagojisine giriş. Pegem Akademi Yayıncılık.

Tarhan, M., Akkaş, E. N. ve Ayvaz, Ü. (2021). Gaining entrepreneurship skills in mathematics education: the middle school mathematics course curriculum of Turkey, International Journal of Mathematical Education in Science and Technology, 52(6), 122.

Uygun M., Mete S. ve Güner E., (2012). Genç Girişimci Adayların Girişimcilik Eğilimi ve Girişimcilik Özellikleri Arasındaki İlişkiler. Organizasyon ve Yönetim Bilimleri Dergisi, 2(4), 145-156

Yüksek Öğretim Kurumu [YÖK] (2018). İlköğretim Matematik Öğretmenliği Lisans Programı.

https://www.yok.gov.tr/Documents/Kurumsal/egitim_ogretim_dairesi/Yeni-

Ogretmen-Yetistirme-Lisans-

Programlari/Ilkogretim_Matematik_Lisans_Programi.pdf.

Wang C. ve Wong P. (2004). Entrepreneurial Interest in University Students in Singapore. Technovation, 24(2), 163-172. https://doi.org/10.1016/S01664972(02)00016-0. 
Bu çalışma için etik kurul izni 01.06.2021 tarih ve 2021/217 sayılı Bolu Abant İzzet Baysal Üniversitesi Sosyal Bilimlerde İnsan Araştırmaları Etik Kurulu'ndan alınmıştır.

\begin{tabular}{|l|}
\hline Araştırmacıların Makaleye Katkı Oranı Beyanı: \\
1. yazar katkı oranı: \% 100 \\
\hline Çıkar Çatışması Beyanı: \\
Yok. \\
\hline Finansal Destek veya Teșekkür Beyanı \\
Bu çalıșma için herhangi bir kurumdan finansal destek alınmamıștır. \\
\hline
\end{tabular}


